\begin{tabular}{|l|l|l|l|l|}
\hline Newsl. Stratigr. & $30(1)$ & $1-32$ & 9 Fig., 7 Tab. & Berlin $\cdot$ Stuttgart, 12.4. 1994 \\
\hline
\end{tabular}

\title{
Upper Eocene - Lowermost Miocene charophyte succession in the Ebro Basin (Spain). Contribution to the charophyte biozonation in Western Europe
}

\author{
by M. Feist, P. Anadón, L. Cabrera, S. J. Chor, F. Colombo and M. Sáez* \\ with 9 figures and 7 tables
}

\begin{abstract}
A charophyte succession has been established in nineteen sections and eight isolated outcrops from the Ebro Basin, ranging from the Priabonian to the Aquitanian. Most assemblages were recovered from continuous sections and their abundance and diversity allow to define a new zonal scheme for the Upper Eocene-Lower Miocene of Europe. The new zonation includes nine subdivisions, based on the distribution of thirty-two species and directly correlated with the mammal standard levels. Changes in diversity, occurring mainly in the Middle and Upper Oligocene, have been related to climatic variations. A new species, Chara sp. A. is also described and figured.
\end{abstract}

Résumé. Une biozonation basée sur les charophytes est établie dans le bassin de l'Ebre, à partir de 19 coupes et 8 gisements répartis du Priabonien à l'Aquitanien. Les associations représentées proviennent pour la plupart de coupes continues; l'abondance et la diversité floristiques observées permettent de définir une nowvelle biozonation, applicable à l'échelle de l'Europe pour l'intervalle Eocène supérieurMiocène inférieur. Cette biozonation comprend neuf subdivisions, fondées sur la répartition de 32 espèces et comparées par corrélations directes avec les niveaux-repères standard des mammifères. Les changements affectant la diversité floristique à l'Oligocène moyen et supérieur sont corrélés avec des variations climatiques. Du point de vue de la systématique du groupe, une nouvelle espèce Oligocène, Chara sp. $A$, est décrite et figurée.

Zusammenfassung. An Hand von 19 Profilen und 8 zusätzlichen Fundstellen wird im Ebrobecken eine Biozonierung nach Charophyten vom Priabonium bis zum Aquitanium vorgenommen. Die Florenassoziationen stammen zumeist aus durchgehenden Profilen. Ihre Häufigkeit und Vielfalt erlauben, ein für Europa gültiges Zonierungsschema des Intervalles Ober-Eozän bis Unter-Miozän aufzustellen. Diese Biozonierung, die auf den Reichweiten von 32 Arten fußst, umfaßst neun Unterteilungen, die direkt mit dem Standard der Säuger-Leitniveaus korreliert sind. Fluktuationen in der Florendiversität im Mittel- und Ober-Oligozän werden auf Klimaschwankungen bezogen. Hinsichtlich der Systematik wird eine neue Art aus dem Oligozän, Chara sp. $A$, beschrieben und abgebildet.

"Authors' addresses: Monique Feist, Laboratoire de Paléobotanique, Université des Sciences et Techniques du Languedoc, Place Bataillon, F-34095 Montpellier, France.

Pere Anadón, Institut de Ciènces de la Terra (J. Almera), CSIC, C. Martí i Franquès s.m., E-08028 Barcelona, Spain,

Lluis Cabrera, Ferran Colombo, Alberto Sáez, Dept. Geol. Dinàmica, Geofísica i Paleontologia, Facultat de Geologia, Universitat de Barcelona, E-08028 Barcelona, Spain.

S. J. Chol, Korean Institute of Energy and Resources, P.O. Box 5, Daedeck Science Town, Daejeon, Korea.

1 Newsietters 30 (1) 


\section{Introduction}

During the Palcogene, predominantly nonmarine sediments accumulated in the eastern part of the Ebro Basin. The carbonate freshwater and brackish deposits have yielded abundant charophytes and the assemblages found in continuous sections show a florizonal succession from the Paleocene to the Lower Miocene. As a result of the stratigraphic studies carried out in the Paleogene sequences of the Ebro Basin (Anadón 1978; Colombo 1980, 1986; Anadón \& Feist 1981; CaBrera 1983; SÁEZ, 1987), it has been established that most of the studied charophyte assemblages are distributed through a number of continuous and correlable stratigraphic sequences (ANADón et al. 1989). This stratigraphic continuity and the quite large number of samples have enabled us to make a local charophyte biozonation. Moreover, this is one of the uncommon cases in which a charophyte biozonation established on a continuous nonmarine Upper Eocene - Lower Miocene stratigraphic sequence can also be referred to a local mammal biozonation based on more than thirty rodent assemblages (Agustí et al. 1987, 1988; ANADón et al. 1987). Our study focusses on the charophyte assemblages found in the sections spanning the Upper Eocene-Lower Miocene interval from the Eastern Ebro Basin, between the Llobregat Valley, to the East, and the Cinca and Ebro valleys, to the West (Fig. 1). These sequences are included between the top of the marine succession attributed to the Priabonian (FERrer 1971) and the bottom of the non-marine Neogene.

Charophytes from the Ebro Basin were first mentioned by DALLons (1930) from the Sierra de Montelar and in the Santa Coloma de Queralt succession. Later, Roselu et al. (1966) based the attribution of the nonmarine sequences at Igualada to the Upper Lutetian on a charophyte assemblage identified by L. Grambast which also recognized Harrisichara lineata in the locality of El Parès (CoLOM et al. 1970) which we will discuss below. Among these first records, the species quoted in the explanation of the geological maps of Calaf and Cardona (RAmírez DEL Pozo et al. 1975a \& b) should be mentioned, although some of them they have not been rediscovered since. The first comprehensive study was by ANADón \& FEIST (1981) who dated and subdivided the succeeding charophyte-bearing sequences of the central part of the Eastern Ebro Basin margin from Thanetian to Bartonian. Later, ANadón et al. (1983) demonstrated the correlation of the uppermost beds of the Pontils Group at the type section, containing Raskyella vadaszi, with the standard Mammal level of La Livinière and the NP17 Nannoplancton zone. These data have been taken into consideration in the Paleogene charophyte biozonation defined by RIvELINE (1986). The charophyte assemblages from the eastern part of the studied area have been partially analyzed by CHOr (1989).

\section{Geological setting}

The Tertiary Ebro Basin is the southern foreland basin of the Pyrenees. This basin is also bounded by the Catalan Coastal Ranges to the SE and the Tberian Chain to the SW. In the Eastern Ebro Basin (Fig. 1) the sedimentary evolution has been mainly influenced by two margins: the Pyrenees (a thrust - sheet belt, Puigderábregas et al. 1986) and the Catalan Coastal Range which is mainly related to a Paleogene strike-slip fault system (ANADón et al. 1985). The Paleogene succession in the Eastern Ebro Basin, up to $2500 \mathrm{~m}$ thick, comprises two 


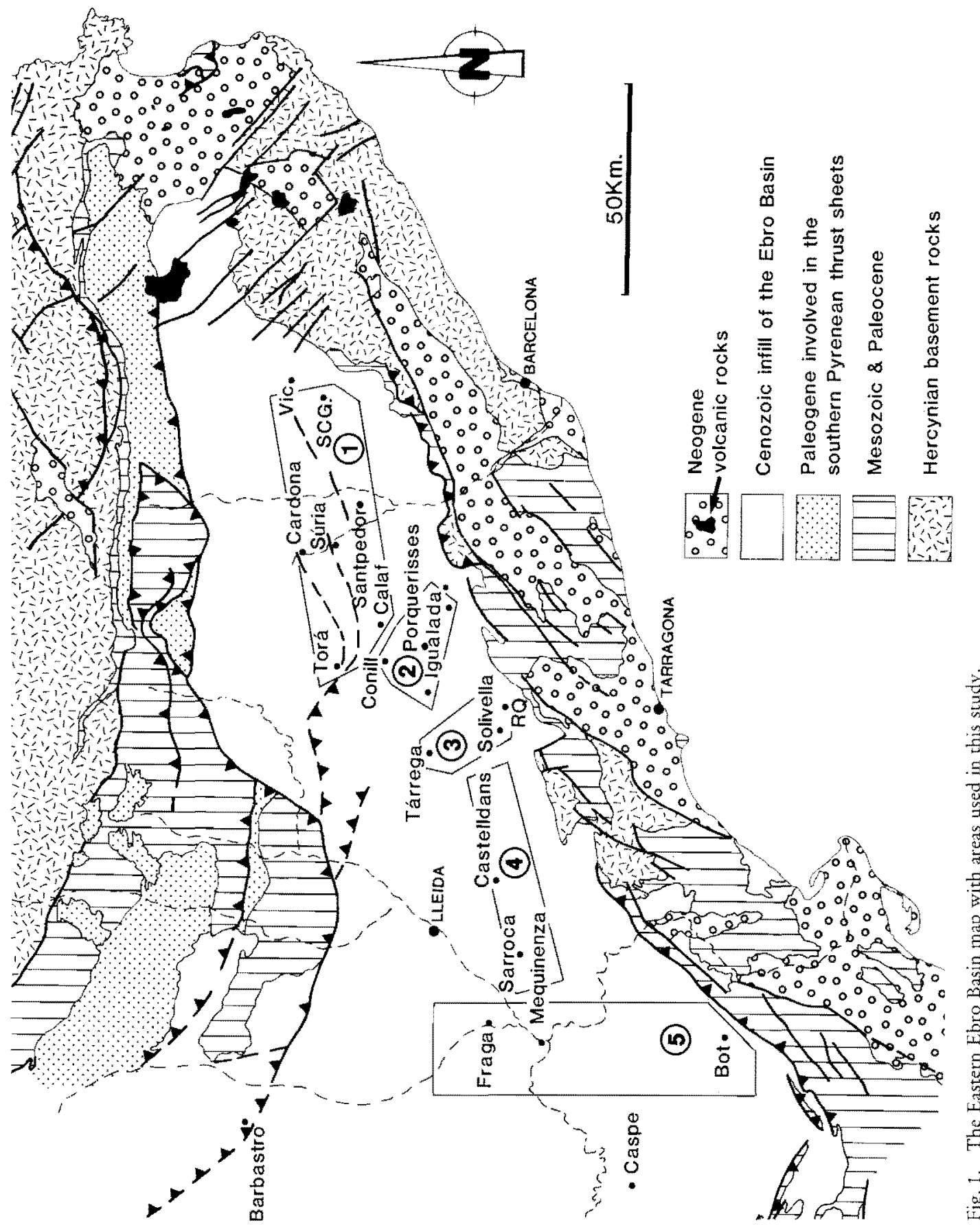




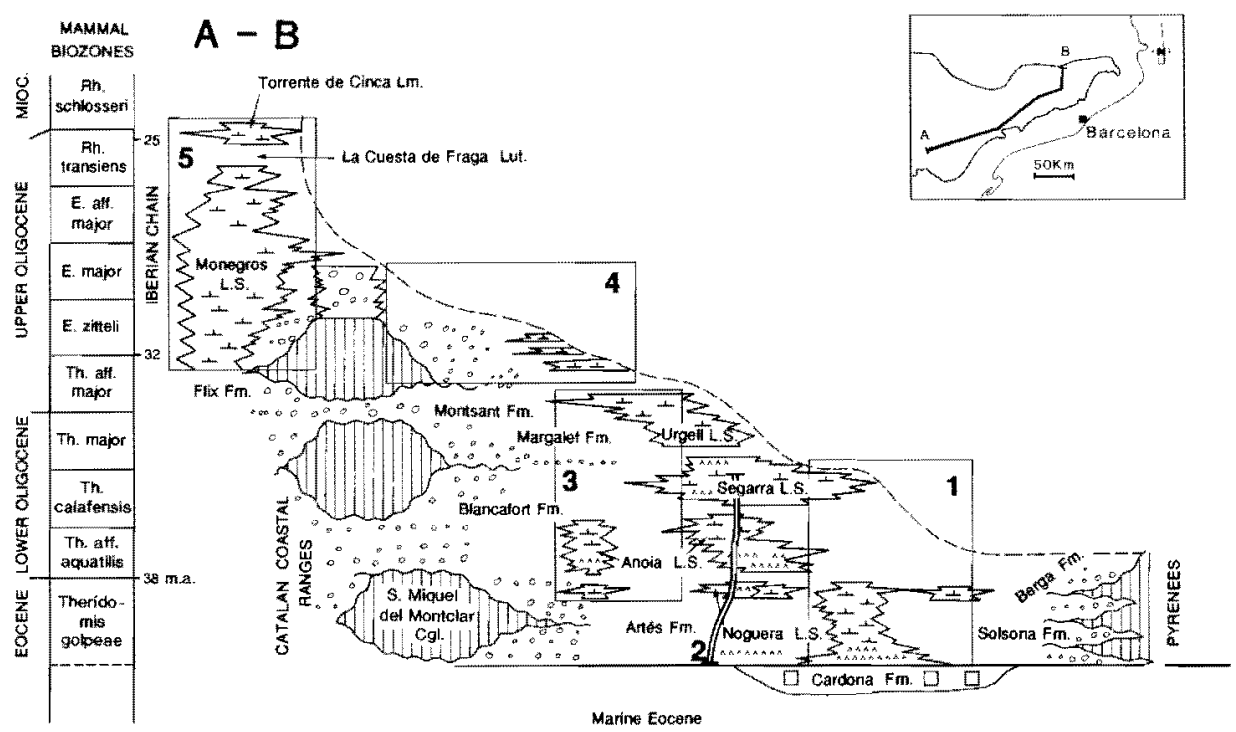

Fig. 2. Schematic stratigraphic cross section of the Upper Priabonian-Lower Aquitanian basin fill in the Eastern Ebro Basin.

important marine - non-marine cycles linked to two major transgressive maxima: Ilerdian (Early Eocene) and Bartonian (Middle - Late Eocene). In the northern areas of the Ebro Basin these two cycles are well recorded whereas in the southern areas non-marine sedimentation was continuous throughout the Paleogene. During the Late Eocene a rapid regression took place and non-marine conditions spread all over the Ebro Basin.

The Upper Eocene - Oligocene basin fill in the Eastern Ebro Basin consists of thick sequences formed in different lacustrine systems which developed in the inner basin zones. These lacustrine systems were fed by marginal alluvial systems. The deposits of the lacustrine systems comprise carbonates, mudstones, sandstones, evaporites and minor, coals. The alluvial deposits consist of proximal conglomerates that pass laterally, basinwards, into sandstone and mudstone dominated sequences. ANADÓN et al. (1989) have distinguished five lacustrine systems for the Upper Eocene to Upper Oligocene sequences of the Eastern Ebro Basin. The lacustrine systems must be regarded as "Depositional Groups" or "Depositional Systems" in the sense of FISHER \& MCGOWEN (1969) and comprise several minor lithostratigraphic units with the range of Formation. Figure 2, based on ANADón et al. (1989) shows the schematic distribution of the lacustrine systems and their relationship with the alluvial systems in the Eastern Ebro Basin. In the present work, we will only mention the units related with the distribution of the charophytes or units with special stratigraphic interest.

The distribution of charophytes presented in this paper is based on samples referred to stratigraphic sections or mammal sites (Figs. 3-8) which have been correlated by mean of key beds in aerial photographs and geologic maps. The result of these lithostratigraphic correlations has been shown in Tables 1 to 5 . The charophyte distribution of the sampled sections 
Upper Eocene - Lowermost Miocene charophyte succession in the Ebro Basin (Spain)

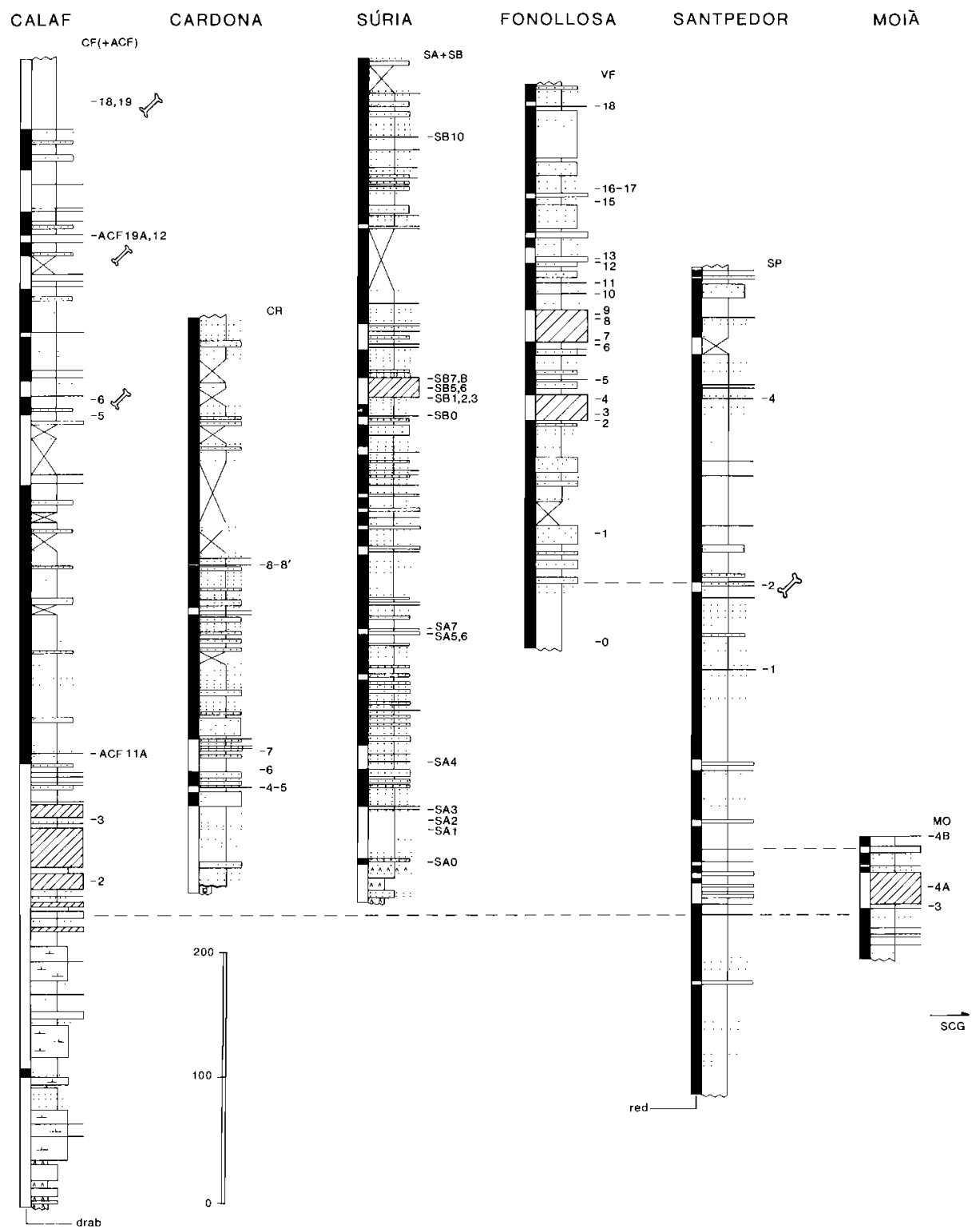

Fig. 3. Stratigraphic logs in the Upper Eocene-Lower Oligocene non-marine deposits of area 1. See Figs. 1 and 2 for location and stratigraphic position. See charophyte distribution in Table 1. 


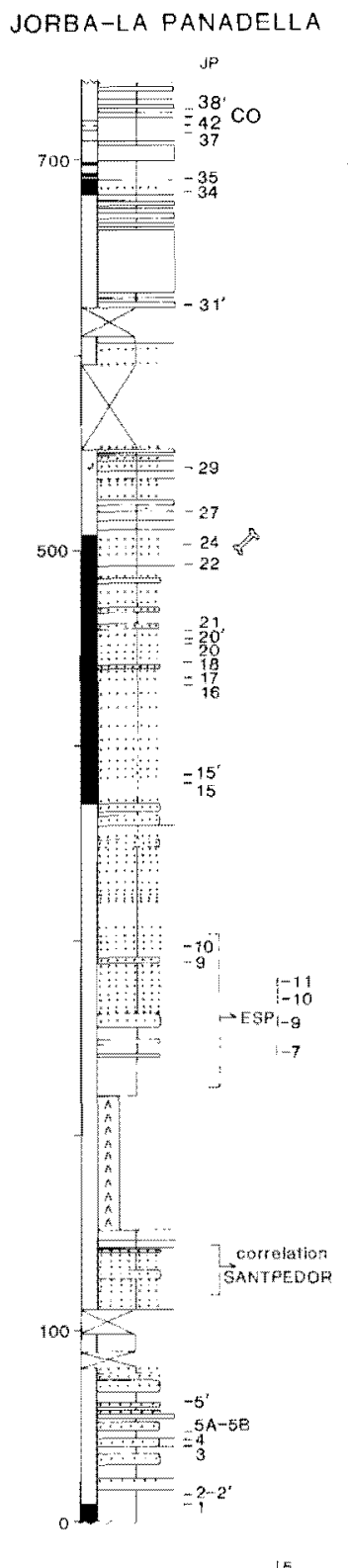

$$
-\quad \rightarrow \text { ESPl }\left.\right|^{5} \text { Fig. } 4 \text {. }
$$

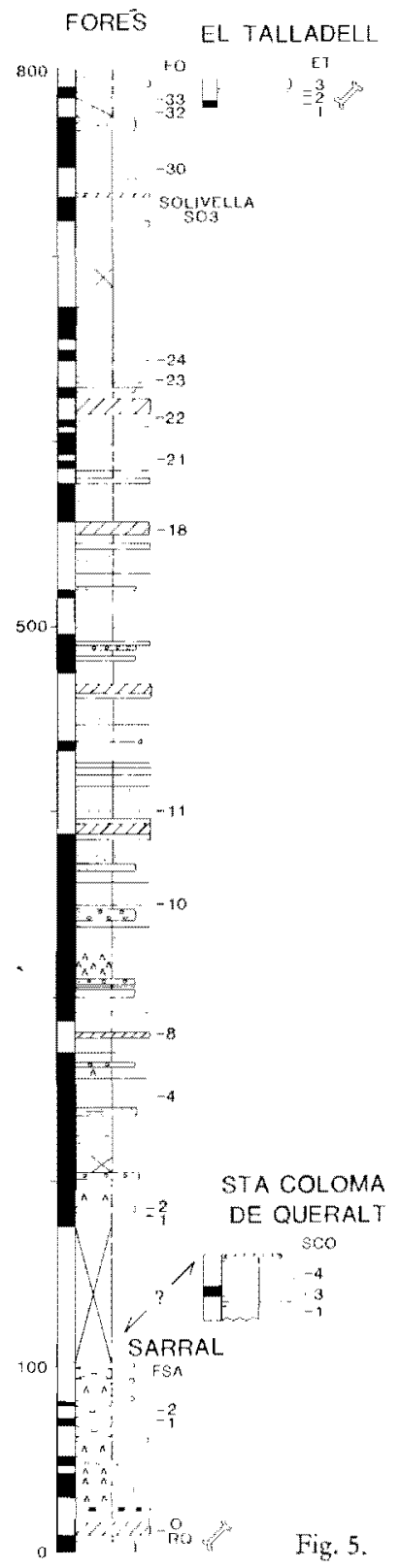

Fig. 4. Stratigraphic log of the Jorba-La Panadella section. Area 2 in Figs. 1 and 2. See charophyte distribution in Table 2.

Fig. 5. Composite stratigraphic log of the Forés and Sarral sections. Correlation with El Talladell and Santa Coloma de Queralt logs are also shown. Area 3 in Figs. 1 and 2. See charophyte distribution in Table 3. 
Upper Eocene - Lowermost Miocene charophyte succession in the Ebro Basin (Spain)

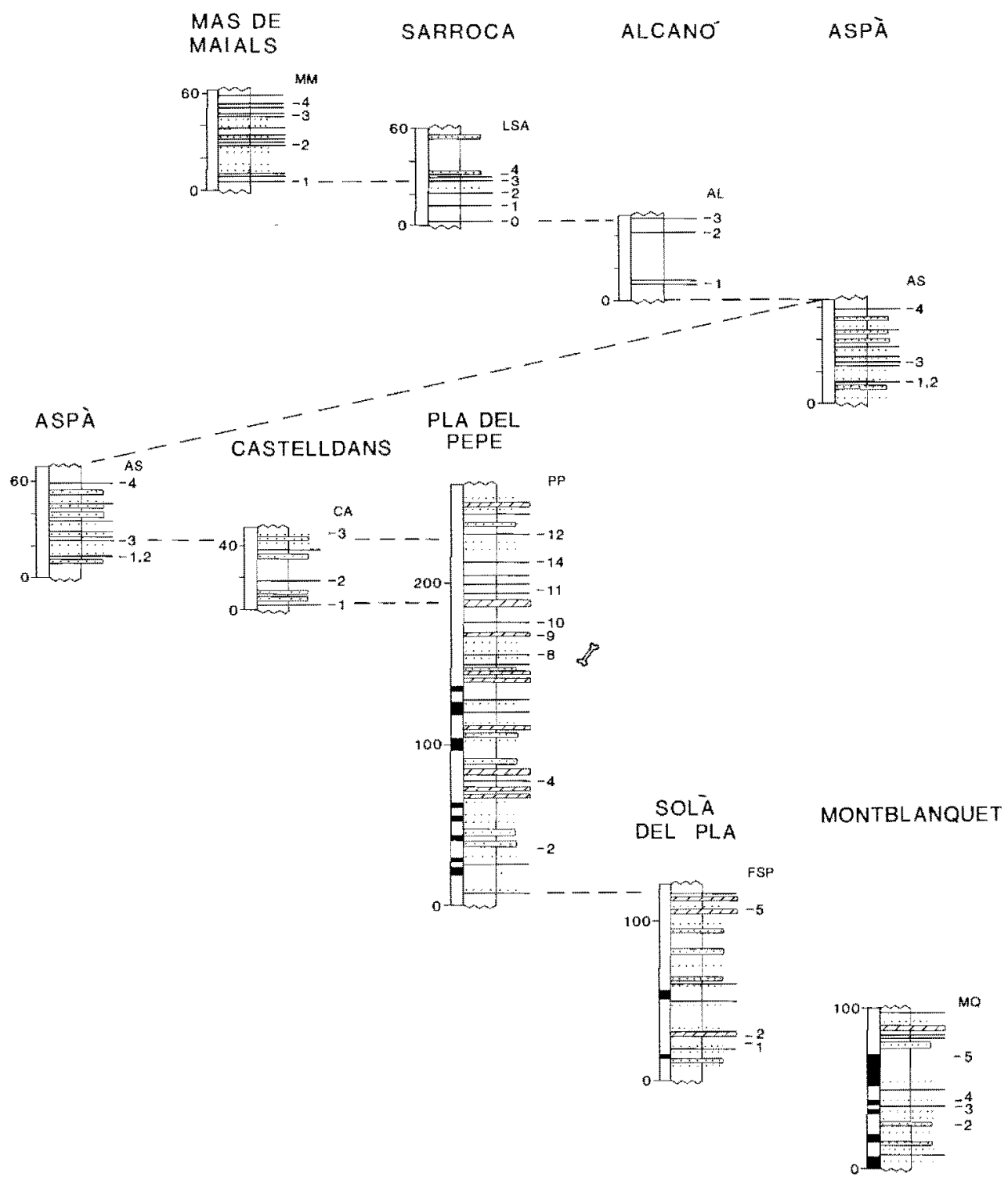

Fig. 6. Stratigraphic logs in the Oligocene deposits of area 4 (Figs. 1 and 2). See charophyte distribution in Table 4 . 
M. FEIST et al.
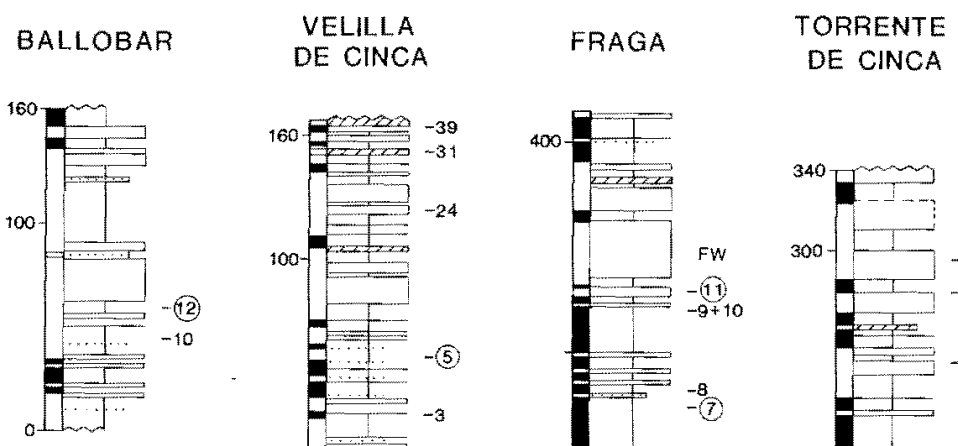

MEQUINENZA
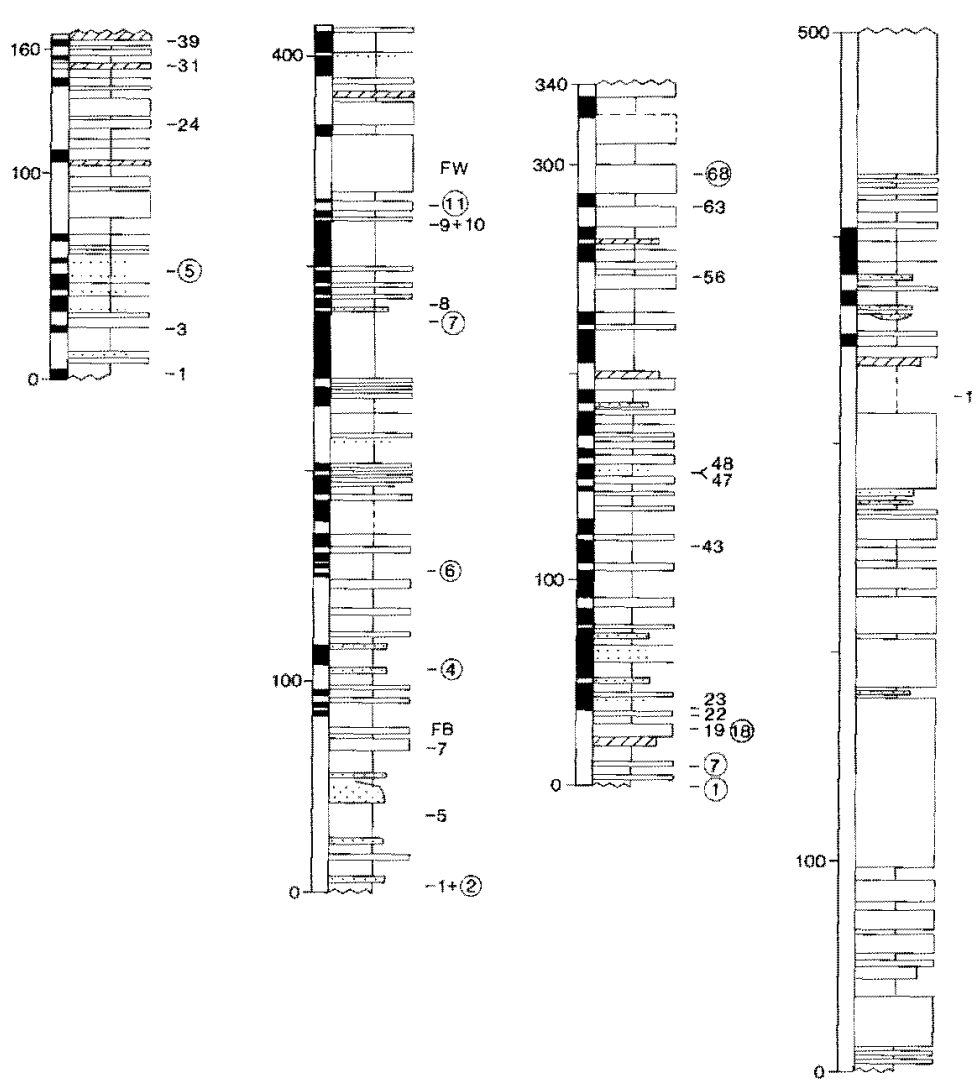

Fig. 7. Stratigraphic logs in the Upper Oligocene deposits of area 5 (Figs. 1 and 2). See charophyte distribution in Table 5.

have been grouped in 5 areas (Figs. 1 and 2) which correspond to stratigraphic record ranges that can be correlated among them. In some places, a certain degree of contemporaneity exists among these ranges.

\section{The charophyte species}

In the Upper Eocene - Lower Miocene sequences of the Ebro Basin, we have found thirtytwo charophyte species. Most of these species have been reported previously from other areas in the numerous studies which have been carried out during the last two decades on the Cenozoic charophyte floras of Europe. In order to simplify the following report, we will frequently refer to the synoptic study of Rrveline (1986) which sums up the papers prior to 


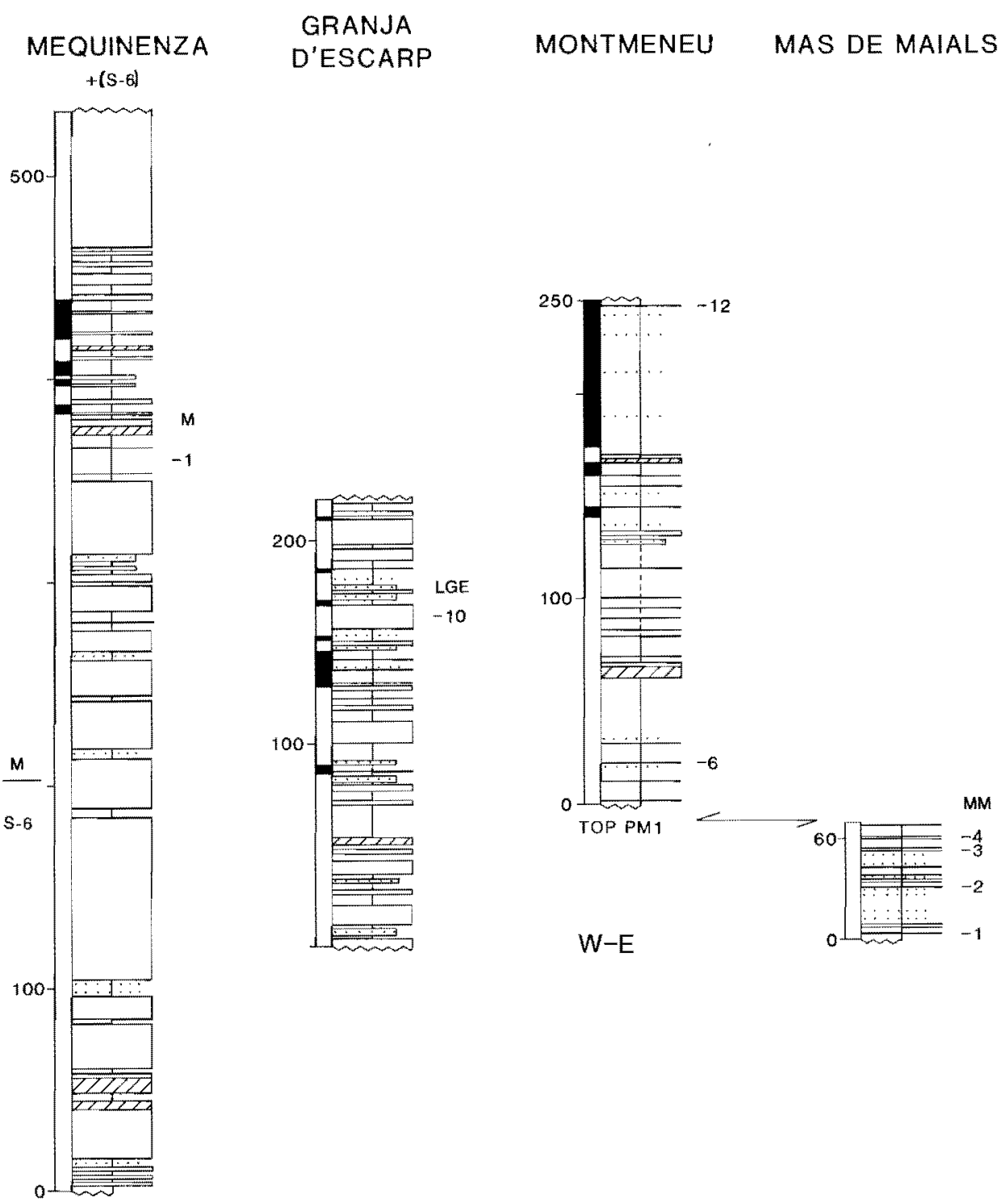

Fig. 8. Stratigraphic logs in the Upper Oligocene deposits of area 5. The correlation corresponds to an E-W cross section. This section links the correlation of profiles in Figure 6 with those in Figure 7. 
1984. Moreover, we refer the Paleogene mammal local biozones to the work of Agusrí et al. (1987) and to the correlation charts of the Paleogene European mammal reference levels of Schmidr-Kirrler (ed. 1987) abbriged MP. The species recognized in the present study, documented below, all belong to the Characeae family.

\section{Harrisichara lineata Grambast 1957}

Distribution and range in the Ebro Basin (area 1, Fig. 1): there is only one record of this species, at the locality of El Parès, in the Vic area (Corom et al. 1970). H. lineata is represented there by more globular specimens and of higher dimensions than in the Paris Basin, but these differences are considered to be within the limits of variation of the species. The fossiliferous bed is placed in the lagoonal facies of the upper part of the Tossa Formation (Lower Priabonian; FERrer 1971), close to the lowermost beds of the non-marine Artés Formation. The species ranges from the Upper Bartonian Raskyella vadaszi zone to the Upper Priabonian Sphaerochara labellata zone, which is defind in this paper; in Saint-Cannat (Southern of France), that is its most recent locality, this species is associated with $H$. tuberculata (FEIST-CASTEL (1977b).

Otber occurrences: Upper Bartonian to Middle Priabonian of the Paris Basin and Southern of France (Feist \& Ringeade 1977; Riveline 1986).

\section{Harrisichara tuberculata (LyeLL) GrambaSt 1957}

Distribution and range in the Ebro Basin (areas 1-3, Figs. 3-5, Tables 1-3): this species occurs abundantly in a number of horizons of Upper Priabonian and Lower Stampian age. The dating of the Calaf Formation is critical for the upper extension limit of the species and thus for the range of the Bembridge zone (CASTEL 1968), or H. tuberculata superzone (Rrvelinf: 1986).

The lowermost stratigraphic occurrence of this species is in the San Cugat de Gavadons mammal site (Theridomys golpeae local zone, MP 19); the uppermost occurrence is in the Conill section, stratigraphically located between the Porguerisses mammal site (Th. calafensis local zone, according to Anadón et al. 1987, MP 21-MP 22) and the Tàrrega mammal site (Th. major zone, MP 23).

Other occurrences: the species, widespread in Europe, has never been mentioned in localities more recent than Lower Stampian. In particular it is absent in the charophyte and mammal locality of Villebramar which is typical of the standard level MP 22 (ScHMidTKrTtLeR (Ed.) 1987). The extension of the species in the Isle of Wight, which is its type area, is also significant; $H$. tuberculata extends from the Bembridge Limestone to the Lower Hamstead Beds (Ferst-Castel 1977a), but it is absent in the superceeding Upper Hamstead Beds (Cerithium Beds, Bouldnor Clif, sample C. 300, University of Montpellier II). Outside of the Ebro Basin, the range of the species is thus restricted to the Upper Priabonian Lower Stampian. However, its presence in the Calaf beds implies that it may extend higher, in the time interval corresponding to charophyte biozone 4, during which some endemic taxa occurred in the Ebro Basin, such as Chara sp. 2 and Nodosochara jorbae (Table 2). 


\section{Harrisichara vasiformis-tuberculata}

This informal species name was proposed to designate the transitional forms from $H$. vasiformis to H. tuberculata (FEIST-CASTEL 1977a). These forms have been taken as index species for the establishment of a Late Eocene zone, due to their wide geographic distribution (RIveline 1986). This zone only covers the lower part of the species range.

Distribution and range in the Ebro Basin (area 1, Fig. 3, Table 1): the occurrence of the species in the Moià section, at the lower part of the Artès Formation, corresponds to its upper range, coexisting with the lowest occurrence of $H$, tuberculata.

Other occurrences: this form has been reported from the Isle of Wight, Paris Basin and South of France (see Rrveline 1986). Its range corresponds to the Middle and Late Priabonian.

\section{Rhabdochara stockmansi GramBaSt 1957}

Distribution and range in the Ebro Basin (areas 1-3; Figs. 3-5, Tables 1-3): the species has been collected in the Upper Eocene Rocafort de Queralt locality and in the upper part of the Calizas de la Panadella Formation at Conill. In addition, $R$. stockmansi occurs in the Solsona Formation, within the Fonollosa section. H. tuberculata is also present in Conill and its association with $R$. stockmansi is typical of the upper part of the H. tuberculata Superzone [Rrvelrne 1986; corresponding to the previously defined Upper Bembridge zone (CASTEL 1968; Ferst \& Ringeade 1977]. In Conill, the association of these two species with Gyrogona medicaginula, whose first occurrence is known to be in the Sannoisian Calcaire de Brie (GRAmbast 1962), corresponds to a Lower Stampian or slightly younger age.

Other occurrences: the species has been reported from a great number of European localities (see Riveline 1986). Its range is the same as H. tuberculata, Upper Priabonian and Lower Stampian.

\section{Rhabdochara major Grambast \& PAul 1965}

Distribution and range in the Ebro Basin (area 3, Fig. 5, Table 3): the species has been found in the Tarrega Formation. Its lowest occurrence is in Solivella, below the El Talladell, also named Tàrega mammal locality, referred to the Th. major zone (MP 23). The upper occurrence of this species is above the Pla del Pepe mammal site of the Th. aff. major zone (MP 25).

Other occurrences: $R$. major has been reported from Northern and Southern France, Switzerland and Germany (see Riveline, 1986). It spans the upper Lower Stampian and Upper Stampian.

\section{Rhabdochara praelangeri CASTEL 1967}

Distribution and range in the Ebro Basin (Fig. 1, area 5, Table 5): the species has been found in the Bot section, from beds of the Upper Oligocene Flix Formation which have been correlated lithostratigraphically with the Gandesa beds which are included in the Eomys zitteli mammal zone (Agustí et al. 1987, MP 26). 
Other occurrences: in addition to the type-locality near Marseille, the species has been reported from numerous localities in France, Germany and Switzerland. It ranges from the Upper Stampian to the Lower Aquitanian (FE1ST-Castel 1977a; Chella1 et al. 1982; RIVELINE 1986).

\section{Rhabdochara langeri (ETTINGSHAUSEN) MADLER}

Distribution and range in the Ebro Basin: (areas 4, 5; Figs, 6, 7; Tables 4, 5): the species is present in the Upper Oligocene sequences of the Margalef Formation and of the Granja d'Escarp Lutites, in the Mas de Maials and Aspà areas. Its lowest occurrence is in beds correlated from stratigraphical position with E. major zone (MP 27). The upper occurrence of the species is in beds referred to the $E$. aff, major zone, equivalent to the MP 27 and MP 28.

Other occurrences: $R$. langeri is widespread in Europe, in the Upper Chattian and Aquitanian (FeIST \& RINGEAdE 1977; RIVELINE 1986).

\section{Rhabdochara aff. altilis FEIST-CASTEL 1977a}

Specimens from the Ebro Basin designated under this name differ from the typical $R$. altilis in lacking a basal funnel and presenting a rounded, instead of truncated, apex (CHOr 1989).

Distribution and range in the Ebro Basin (area 1, Fig. 3, Table 1): this form is represented in the Artés Formation. Its lowest occurrence is in the lower part of the Calaf and Moia sections, in beds several tens of metres stratigraphically above the Sant Cugat mammal site (Th. golpeae zone) which can be referred indifferently to the $T h$. golpeae or to the $T h$. aff. aquatilis zones (MP 19/20 or MP 21). The upper occurrences of this form is in the Santpedor mammal locality attributed to the Lower Oligocene Th. aff, aquatilis zone (Agustí et al. 1987, MP 21), From Rodent evidence, this form extends, in the Ebro Basin, from the Lower Priabonian to the Lower Stampian.

Occurrences of Rh. altilis: typical representatives of the species have been reported from two localities of the Mormoiron Basin, in Southern France, both of Upper Priabonian age (Feist-Castel 1977a).

\section{Rhabdochara aff. raibocarpa FEIST-CASTEL 1977a}

Close to $R$. raibocarpa in general shape and apical structure of the gyrogonites, the catalan form differs clearly in its smaller dimensions.

Distribution and range in the Ebro Basin (areas 1,2; Figs. 3,4; Tables 1,2): this form occurs abundantly in some levels of the Artès, Süria and Solsona Formations. Its lowest occurrence is stratigraphically located between the Sant Cugat de Gavadons and Santpedor mammal sites, respectively reported to the $T h$. golpae (MP 19) and Th. aff. aquatilis (MP 21) zones. The highest occurrence of the species is in the Fonollosa mammal site, referred to the Th. calafensis zone (MP 21-MP 22).

Occurrences of $R$ raibocarpa: The species has been reported only from the type locality, in the Mormoiron Basin (South of France). 


\section{Stephanochara aff. vectensis (Groves) Grambast in Riveline 1986}

Two different forms are grouped under this denomination: a) In Bed 2 of the Forès section, specimens closely allied to $S$. vectensis but with a more conical shape and a slightly more prominent basal part; the dimensions do not differ significantly. b) In beds 0 and 1 of the Sarral section, the form represented differs from typical representatives of the species only by their distinctly smaller dimensions.

Distribution and range in the Ebro Basin (area 3, Fig. 5, Table 3): the lowest occurrence of S. aff. vectensis is in the Upper Priabonian Rocafort de Queralt mammal site, referred to the Th. golpae zone (MP 19). Its highest occurrence is above bed 2 in the Forés section, attributed the Th. calafensis zone (MP 21-MP 22).

Occurrences of Stephanochara vectensis: the species has been reported from the Upper Priabonian of the Paris Basin and from the uppermost Bembridge Marls of the Isle of Wight. Reexamination of material from the Bembridge Limestone did not confirm the presence of $S$. vectensis, notably the specimens collected by Professor D. Curry at Hamstead Ledge (C. 313, Professor Grambast charophyte collection, Montpellier University) and Gurnard Bay (C. 315). Further collectings at Whitecliff Bay (C. 2685c in FeIST-Castel 1977a) were also negative. The species is absent, too, in the Bembridge Oyster Beds, twelve metres above the Bembridge Limestone (C. 316). Our research has shown that the range of this form, which is the index-species of a charophyte biozone, is restricted, in the Isle of Wight, to the Insect Limestone of the Bembridge Marls (specimens V. 18335, Natural History Museum, London).

\section{Stephanochara aff. pinquis GRAMBAST in RIVELINE 1986}

The forms of the Ebro Basin allied to S. pinquis show similar general shape and dimensions but they differ in the less prominent apical nodules. This difference does not seem to be a result of a lower degree of calcification, as the spiral cells are clearly convex and thus well calcified.

Distribution and range in the Ebro Basin (area 3, Fig. 5, Table 3): S. aff. pinquis occurs in the Tàrrega Formation, in the uppermost beds of the Forès and El Talladel sections, attributed to the Upper Stampian Th, major zone (MP 23), on mammal evidence.

Occurrences of S. pinquis: this species is restricted to the Lower Stampian (Rrverine 1986). In particular, in the Sierra Palomera (Teruel Province, Spain) it is associated with the Rodent Theridomys aquatilis (Adrover et al. 1983), attributable to the MP 21.

\section{Stephanochara lychnothamnoides FEIST in FeIST \& RINGEADE 1977}

Distribution and range in the Ebro basin (area 1, Fig. 3, Table 1): this species occurs only in the uppermost beds of the Calaf section which are attributed to the $T$. calafensis zone (MP 21-MP 22).

Other occurrences: S.lychnothamnoides has previously been reported from the Upper Eocene of the Aquitaine Basin, France (Feist \& Ringeade 1977) and from the Lower Oligocene of the Western Iberian Chains (Adrover et al. 1983). 


\section{Stephanochara aff. edwardsii GRAMBAST in RiveLINE 1986}

This form closely resembles typical representatives of the species, apart from its smaller dimensions. It shows little variation in its different occurrences in the Ebro Basin.

Distribution and range in Ebro Basin (area 1, Fig. 3, Table 1): S. aff. edwardsii occurs in several horizons of the Artès, Surria and Solsona Formations, notably in the Sant Cugat de Gavadons, Santpedor and Fonollosa mammal ocalities. It ranges from the $T h$. golpeae to the Th. calafensis zones (MP 19 to MP 21-MP 22), thus from the Upper Priabonian to the Lower Stampian and lower Upper Stampian.

Occurrences of $S$. edwardsii: the species was previously recorded only from the Paris Basin and from the Isle of Wight where its extension is restricted to the Lower Priabonian ("Lower Ludian"; Rrveline 1986).

\section{Stephanochara ungeri FEIST-CASTEL 1977b}

Extension and range in the Ebro Basin (area 5, Fig. 7, Table 5): the species occurs in several sections of the Mequinenza area. Its lowest occurrence is in the Upper Oligocene Fraga B-7 locality, related to the $E$. aff. major zone (MP 27). The species extends into the Lower Miocene, deduced from the stratigraphic position of beds 24 to 39 in the Vellila de Cinca section, 20 to $40 \mathrm{~m}$ above the mammal site referred to the Rbodanomys schlosseri zone (MN 1 ).

Other occurrences: the species is widespread in the Upper Oligocene and Lower Miocene (Feist-CAStel 1977b) and, according to PAPP (1951), persists until the Tortonian. S, ungeri is recorded under its former invalid name "Croftiella escheri" by FeIst \& Kissling (in KissLing 1974), from the Lower Chattian onward and by BERGER (1986) under the name "gr. ungeri" in the $S$, ungeri zone, parallelized with the Aarwangen Mammal zone, also referred to the MP 27. We thus see that the first appearance of $S$. ungeri occurs simultaneously in the Ebro Basin and in the Swiss Molassic Basin. This fact strengthens the value of the species as zonal indicator.

\section{Stephanochara berdotensis FEIST in FEIST \& RINGEADE 1977}

Extension and range in the Ebro basin (area 5, Fig. 7, Table 5): the species occurs in several horizons of the Upper Oligocene sequences of the La Cuesta de Fraga Lutites and in the Lower Aquitanian Torrente de Cinca-68 mammal locality. The appearance of S. berdotensis slightly below the Upper Oligocene Fraga W-7 locality, referred to the $R$. transiens zone (Agustí et al. 1987, 1988; MP 30: SCHMIDT-Kmrler 1987) considerably extends its range, previously known as restricted to the Upper Aquitanian and thus the charophyte zone based on its lowest occurrence is no longer defined.

Other occurrences: this species was recorded previously from the Upper Aquitanian of the Aquitaine Basin, which is its type area, and from several localities of the same age in the Swiss Molassic and Paris Basins (see Rivel.rne 1986).

\section{Lychnothamnus longus CHOI 1989}

Extension and range in the Ebro Basin (areas 1-3; Figs.3-5; Tables 1-3): L. longus occurs abundantly in the Artés Formation and lateral equivalent successions as well as in the La 
Panadella-Montmaneu Limestone, referred to the Th. calafensis one, but it does nor persist in the overlying Tàrega Limestone. It thus occurs in the Upper Eocene and Lower Oligocene. The lowest occurrence of this species is in the lowest Calaf bed and in the Moia section. Both sites are placed stratigraphically between the Sant Cugat de Gavadons and the Santpedor mammal sites (Th. golpeae - Th. aff. aquatilis biozones; MP 19-MP 21). Its uppermost occurrence is situated between the Porquerisses and Tarrega mammal sites, referred to the $T h$. calafensis (MP 21-MP 22) and Th. major zones (MP 23), respectively.

Other occurrences: L. longus has not yet been recorded from elsewhere.

\section{Nodosochara jorbae CHOI 1989}

Extension and range in the Ebro basin (areas 1,2; Figs. 3,4; Tables 1,2): this species is well represented in the Artés Formation and lateral equivalent successions. It is particularly abundant in the Th. aff. aquatilis zone (MP 21). Its possible occurrence in the Th. golpeae (MP 19) and Th. calafensis (MP 21-MP 22) zones can not be disregarded.

Other occurrences: the species is presently known only from the Ebro Basin.

\section{Gyrogona caelata (REID \& Groves) Grambast 1956}

Extension and range in the Ebro Basin (areas 1, 2; Figs. 3, 4; Tables 1, 2): the species is well represented in the Jorba La Panadella, Surria and Fonollosa sections as well as in the Artès Formation and equivalent sequences, until the base of $\mathrm{La}$ Panadella Limestone. Its lowest occurrence is situated between the mammal sites of Sant Cugat de Gavadons (MP 19) and Santpedor (MP 21). The uppermost occurrence of $G$. caelata in the upper part of the Fonollosa section referred to the Th. calafensis zone (MP 21-MP 22) extends its range a few higher than the Lower Stampian.

Other occurrences: $G$. caelata is widely distributed in Europe, from the Upper Lutetian (Grambast 1958) to the Lower Stampian (Feist-Castel 1971, Riveline 1986).

\section{Gyrogona medicaginula LAMARCK}

Extension and range in the Ebro Basin (area 2, Fig. 4, Table 2): this species has been found only in the locality of Conill. The Conill beds are stratigraphically located between the mammal sites of Porquerisses (Th. calafensis zone, MP 21-MP 22) and Tàrega (Th. major zone, MP 23). Thus, up to date the exact range of this species in the Ebro Basin remains uncertain in relation to the mammal biozones.

Other occurrences: The species was previously known from the Lower to Upper Stampian of the Belgium and Paris Basin (Rrveline 1986) as well as from the Bavarian Untere Süsswasser Molasse (BAumgartner 1985).

\section{Chara sp. 1 CHOI 1989}

Distribution and range in the Ebro basin (area 1, Fig. 3, Table 1): this form occurs scarcely in the Upper Eocene and Lower Oligocene beds of the Súria and Torà sections. The stratigraphic 
M. Fesst et al.

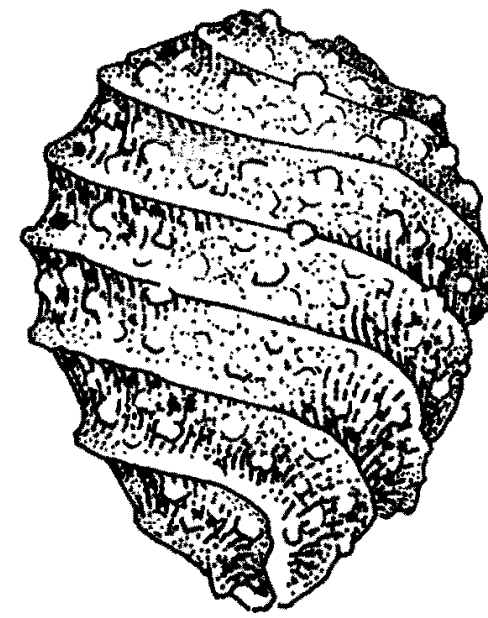

Fig, 9. Chara sp. A, lateral view, X80. From the Aspà section, bed 4; Upper Oligocene.

range of this species cannot be precisely determined due to its scarcity and its absence in well dated localities.

\section{Chara sp. 2 CHOr 1989}

Distribution and range in the Ebro Basin: (areas 1, 2; Figs. 3, 4; Tables 1, 2); this form has been found in beds of the Artés and La Panadella Formations and lateral equivalent sequences. Its lowest occurrence is in levels stratigraphically situated between the mammal sites of Sant Cugat de Gavadons (Th. golpeae zone, MP 19) and Santpedor (Th. aff. aquatilis zone, MP 21). The uppermost occurrence is in beds overlying the Porquerisses mammal locality (Th, calafensis, MP 21-MP 22).

\section{Chara microcera Grambast \& PAUl 1965}

Distribution and range in the Ebro Basin (areas 3-5; Figs, 5-7; Tables 3-5): this species occurs in a number of localities, from the Upper Stampian to the Lower Aquitanian. Its occurrence in bed 3 of the Solivella section, referred to the Th. major zone (MP 23) extends its range, which was previously known as starting in the Heimersheim (MP 24) biozone (CHellar et al. 1982).

Other occurrences: Chara microcera is widespread in Europe, where it spans the Upper Oligocene and the Lower Miocene.

\section{Chara notata Grambast \& PAUL 1965}

Distribution and range in the Ebro Basin (areas 4, 5; Figs. 6, 7; Tables 4, 5): the species occurs in the upper sequences studied here, in the Late Oligocene and at the Oligocene-Miocene transition. Its lower occurrence is in the Aspà section, referred to the E. major zone (MP 27) 
this fact resulting in a noticeable larger, lower extension of its range. Its uppermost occurrence is in the Velilla de Cinca Section, in beds corresponding to the Early Aquitanian Rh. sclosseri zone.

Other occurrences: this species is widespread in the Aquitanian and rarer in the Upper Oligocene. In the Swiss Molassic Basin, C. notata appears in the Rickenbach mammal horizon (Berger 1986), attributed to the MP 29 standard level.

\section{Chara sp. A (Fig, 9)}

This form shows new conjunction of characters, but the diagnosis of a new species is not possible due to the small number of specimens found so far. The specimen represented (Fig. 9) shows a charoid apex and a pointed basal part that would characterize the genus Hormichara but, in addition to the fact that the spiral cells are provided with a Chara-like ornamentation, the population of Chara notata from the Aspà-4 bed includes specimens with a basal stalk and could be interpreted as transitional with the new form, that would question the validity of a new taxon.

Distribution and range in the Ebro Basin (area 4, Fig. 6, Table 4): Chara sp. A has been found in the Mas de Maials and Sarroca sections, in beds correlated with the Upper Oligocene E. aff. major zone (MP 27 and MP 28).

\section{Hornichara lagenalis (Straub) HUANG \& Xu in WANG, Hung, Yang \& Lee 1978)}

Distribution and range in the Ebro Basin (area 5, Fig.7, Table 5): this species only occurs in some Upper Oligocene beds of the Mequinenza area. Its lowest occurrence is in bed Fraga $\mathrm{B}-5$, that is placed few metres above the Fraga B-2 mammal site, attributed to the E, major zone (MP 26-27). The uppermost occurrence of H. lagenalis is in the Fraga W-4 mammal site, also included in the $E$. aff. major zone.

Other occurrences: $H$. lagenalis was reported from the Upper Oligocene and Lower Miocene of the Swiss and German molassic Basins (Straub 1952, Feist-Castel 1977c) as well from Aquitaine (Ferst \& RingeAde 1977). However, previous Miocene records are now to be reconsidered and the species probably extends in fact from the Wynau (MP 27) to the Rickenbach (MP 29) mammal levels (BERGER 1986) and is thus restricted to the Oligocene, as it does in the Ebro Basin.

\section{Nitellopsis (Tectochara meriani (L. \& N. Grambast) Grambast \& Soulié-Märsche 1972}

Distribution and range in the Ebro Basin (areas 2, 4, 5; Figs. 4, 6, 7; Tables 2, 4, 5): the species is well represented, from the Lower Stampian onward. Its lowest occurrence is in bed 21 of the Jorba-La Panadella section, $40 \mathrm{~m}$ below the Porquerisses mammal site (bed $24, T h$. calafensis zone, MP 22), which is $20 \mathrm{~m}$ below bed 27 , containing the last representatives of $H$. tuberculata.

Other occurrences: $N$. meriani is widely distributed in Europe, from the Lower Oligocene to the Upper Tortonian. Its known lowest occurrences were reported by FEIST \& RINGEADE (1977) from the mammal localities of Ruch and Pouquette, in the Aquitaine Basin, which are referred to the MP 21 standard level (RINGEADE 1987).

2 New letrers 30 (1) 


\section{Lamprothamnium sp.}

The presence of this genus is interesting in its palacoecological significance; Lamprothamrium is a sure indicator of present and past saline lakes. Recent analogs of such environments in the Coorong area (south of Australia) are interpreted by BURNE et al. (1980) as being affected by seasonally varying salinities under semi-arid conditions.

Extension and range in the Ebro Basin (area 5, Fig. 7, Table 5): this form has been found in some beds of the La Panadella, Fraga and Torrente de Cinca sequences dated from the Upper Oligocene by other fossil assemblages.

\section{Sphaerochara subglobosa (GROVES) HORN of RANTZIEN 1959}

Distribution and range in the Ebro Basin (area 3, Fig. 5, Table 3); the species was only found in the lower part of the Forès section, attributed to the Th. calafensis zone (MP 21-MP 22).

Other occurrences: S. subglobosa was recorded from the Hampshire and Lower Saxonian Basins as well as from two localities in Southern France (see Riveline 1986). Taking in account the occurrences in the Ebro Basin, the species extends from the Upper Priabonian to the Lower Stampian.

\section{Sphaerochara aff. subglobosa}

Specimens incompletely calcified or not well preserved resembling $S$. subglobosa in their general shape, apex structure and ornamentation are doubtfully attributed to this species (CHOI 1989).

Distribution and range in the Ebro Basin (area 1, Fig. 3, Table 1): this form occurs in the Moià, Calaf and Fonollosa sections, from the Upper Priabonian to the Lower Stampian. Its lowest occurrence is stratigraphically placed between the Sant Cugat de Gavadons and Santpedor mammal localities ( $T h$. golpeae and $T h$. aff. aquatilis zones), its uppermost occurrence in the uppermost Calat mammal site (Th. calafensis zone).

\section{Sphaerochara labellata FEIST in FEIST \& RINGEADE 1977}

Distribution and range in the Ebro Basin (area 3, Fig. 5, Table 3): the species is only represented in the Upper Priabonian mammal locality of Rocafort de Queralt attributed to the Th. golpeate zone (MP 19).

Other occurrences: $S$. Labellata was previously recorded from the Baby-2 locality, in Aquitaine, attributed to the Upper Priabonian MP 20 mammal standard level (RINGEADE, 1987).

\section{Sphaerochara hirmeri (RASKY) MäDLER, emend. HorN af RaNTzien \& Grambast 1962}

Distribution and range in the Ebro Basin (areas 4, 5; Figs. 6, 7; Tables 4, 5): early representatives of the species occur in bed 4 of Pla del Pepe section, which is correlated with the $T h$. 
aff. major zone (MP 25). The species was also found in bed 19 of the Torrente de Cinca section, just above the TC-18 mammal locality, referred to the Eomys aff. major zone (MP 27).

Other occurrences: $S$. hirmeri is widespread in the Upper Oligocene of the European Basins but according to Riveline (1986), the species occurs in the Late Eocene Bembridge Marls of the Isle of Wight and its persistance into the Miocene is doubtful. Apart from the isolated record of the species in the Late Eocene, its first occurrence is from the Upper Stampian locality of Saint-Vincent-de-Barbeyrargues (Languedoc; Grambast 1962), referred to the MP 25 mammal standard level, thus quite simultaneously as in the Ebro Basin.

\section{Sphaerochara ulmensis (STRAUB) GRAMBAST}

Distribution and range in the Ebro Basin (areas 4, 5; Figs. 6, 7; Tables 4, 5): the lowest occurrence of the species is in Aspà-4, which is tentatively referred to the E. major zone (MP 27). Its uppermost occurrence is in parts of the Torrente de Cinca and Vellila de Cinca sections attributed to the $R h$. transiens zone (MP 30). As reported below, records from other areas confirm this attribution.

Other occurrences: S. zimensis was recorded, in Europe, from the Upper Stampian to Tortonian in Switzerland, from the Chattian and Aquitanian of Germany (MÄDler 1955) and from the Aquitanian of Southern France (FEIST-CASTEL 1977a). The species is widely distributed as it was also reported from the Upper Oligocene of China (Huang 1978, PI. 9, Figs. 1-5). The lowest occurrences of the species is in the Aarwanger Molasse of Switzerland (HORN AF RANTZIEN 1959), referred to the MP 27 mammal standard level.

\section{Charophyte biozonation of the Upper Eocene-Upper Oligocene sequences}

The wide geographical extension and relatively short ranges of charophyte species prevails on subdividing and correlating Cretaceous and Paleogene non-marine sequences. With regards to the Paleogene of Europe, after the pioneer studies of Castel. (1968) and Grambast (1972), RIVELINE (1986) defined 20 zones based on the first occurrences of charophyte index species and on their assemblages. Our study on Paleogene Mesogena floras gives us the opportunity to update this biozonation with defining new zones and delimitating others more precisely. We will first determine the succession of the local zones established in the Ebro Basin with the species represented (Table 6), then we will place them in the context of the whole Paleogene Zonal succession of the European Basins (Table 7), with the inferred modifications (Table 7).

\section{A. Charophyte succession in the Ebro Basin}

\section{Local biozone 1}

Definition: interval defined by the presence of Harrisichara lineata. This species occurs, in the Vic area (Colom et al. 1970), at the upper part of the Lower Priabonian Tossa Formation (FERRER 1971, LUterbacher et al. 1973). The species ranging up to the Upper Priabonian Sphaerochara labellata zone, its datation cannot be established precisely. 
M. Feist et al.

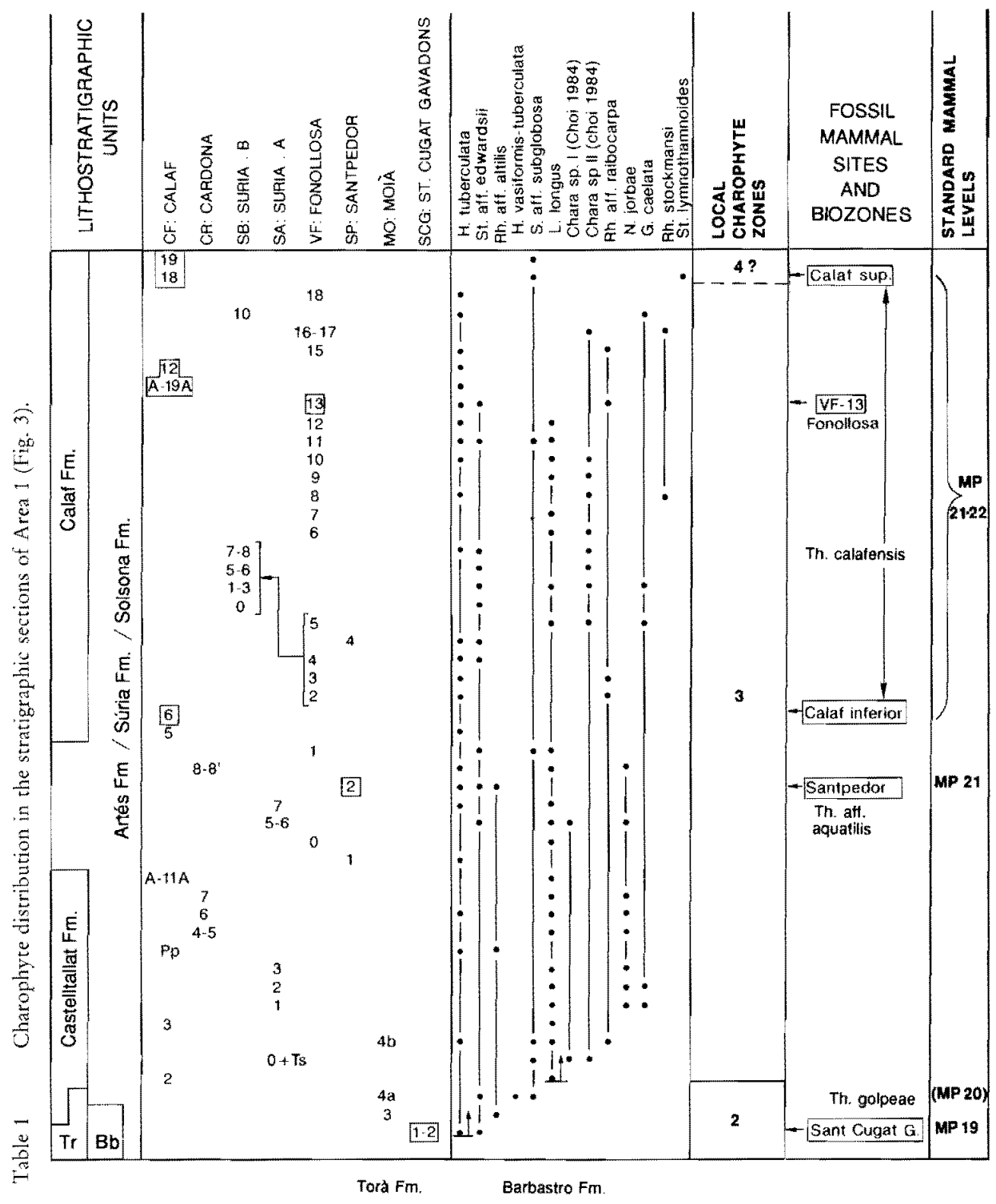


Upper Eocene - Lowermost Miocene charophyte succession in the Ebro Basin (Spain)

Table 2 Charophyte distribution in the stratigraphic sections of Area 2 (Fig, 4).

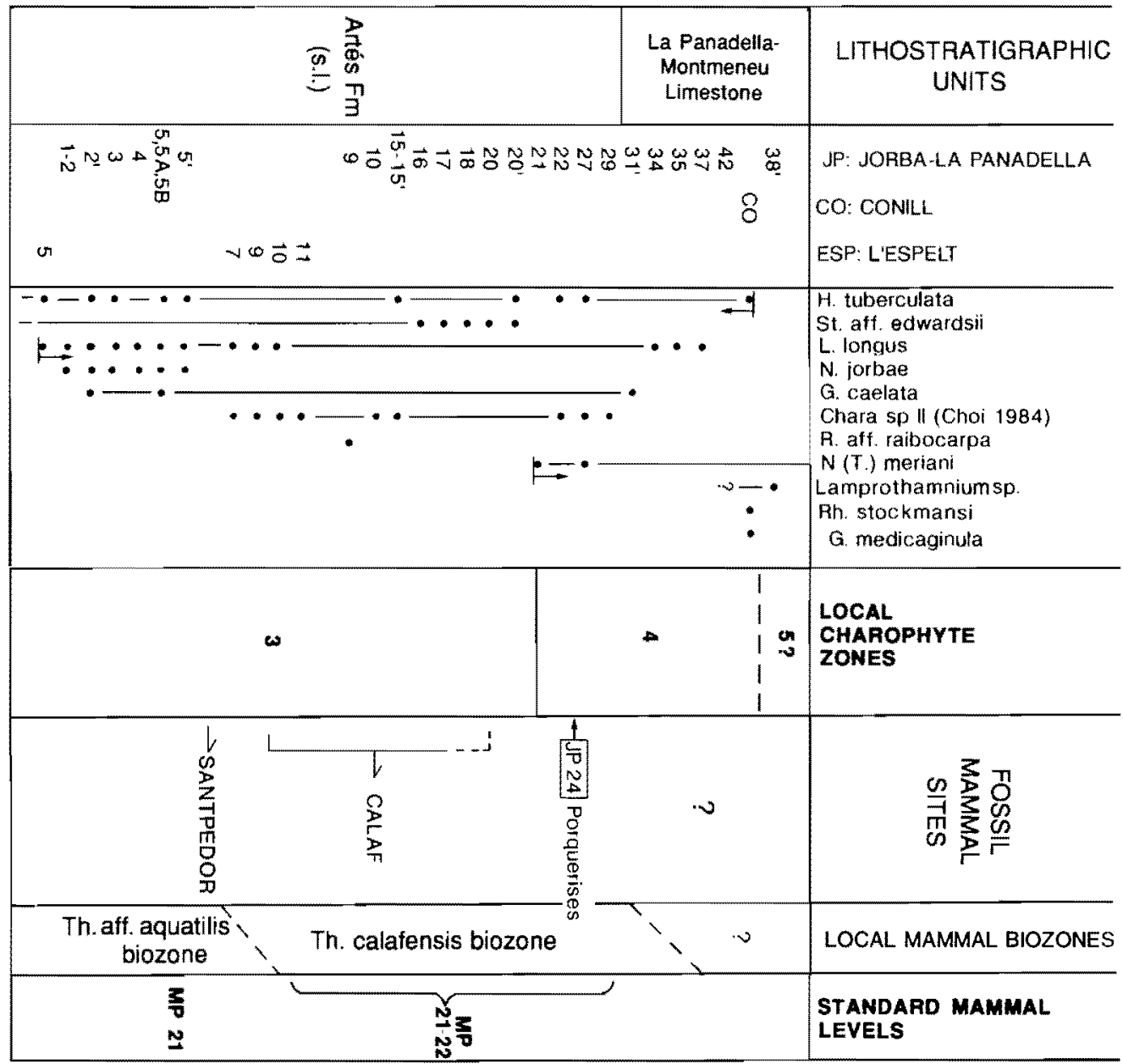

Local biozone 2

Definition: interval between the first occurrence of Sphaerochara labellata and the first occurrence of Lychnothamnws longus in the Ebro Basin. Early forms of S. labellata occur in the Rocafort de Queralt sequences exposed at the locality with the same name. This zone is also developped in the Moià and Sant Cugat de Gavadons sections.

Important species: $H$. tuberculata and $S$. aff. vectensis and $R$. stockmansi which appear simultaneously with $S$. labellata.

Zonal attribution: Spbaerochara labellata zone. This newly defined zone corresponds to the lower part of the Stephanochara vectensis zone of RIVELINE (1986). Correlation of $S$. 
Table 3 Charophyte distribution in the stratigraphic sections of Area 3 (Fig. 5).

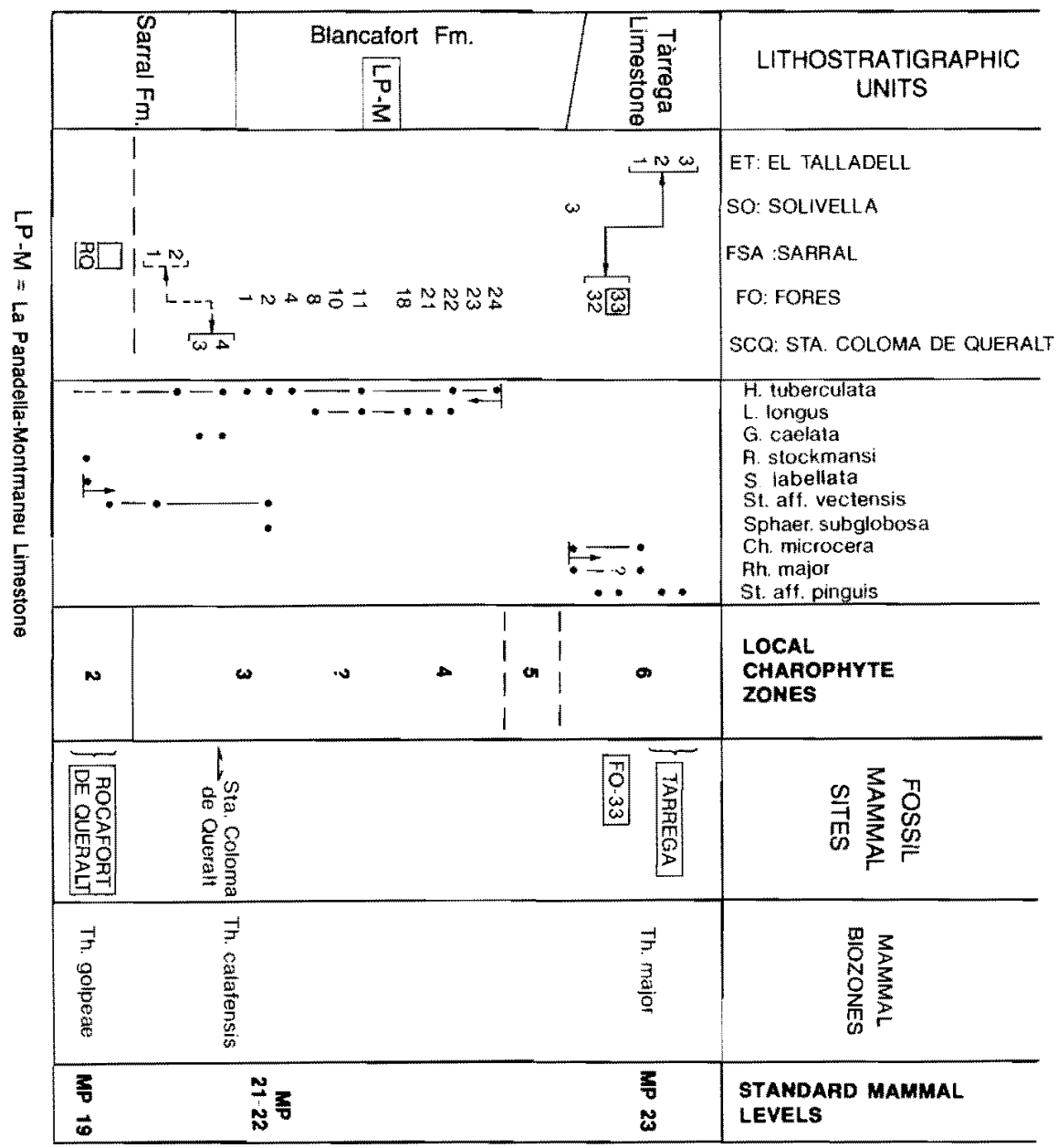

labellata zone with the MP 19-MP 20 mammal standard levels is based on common localities of charophytes and mammals in the Aquitaine and Ebro Basins. This zone is widely represented, in particular in the Calcaire d'Issigeac, in Aquitaine, and in the Bembridge Limestone of the Isle of Wight (FeIst \& Ringeade 1977; FeIst-CASTEL. 1977a).

\section{Local biozone 3}

Definition: interval between the first occurrence of Lycbnothamnus longus and the first occurrence of Nitellopsis meriani. Early forms of L. longus occur in the Calaf and in the Espelt sections and the zone is developped in the lower part of the Artés Formation exposed in these sections, as well as in the Forès section. 
Table 4 Charophyte distribution in the stratigraphic sections of Area 4 (Fig. 6).

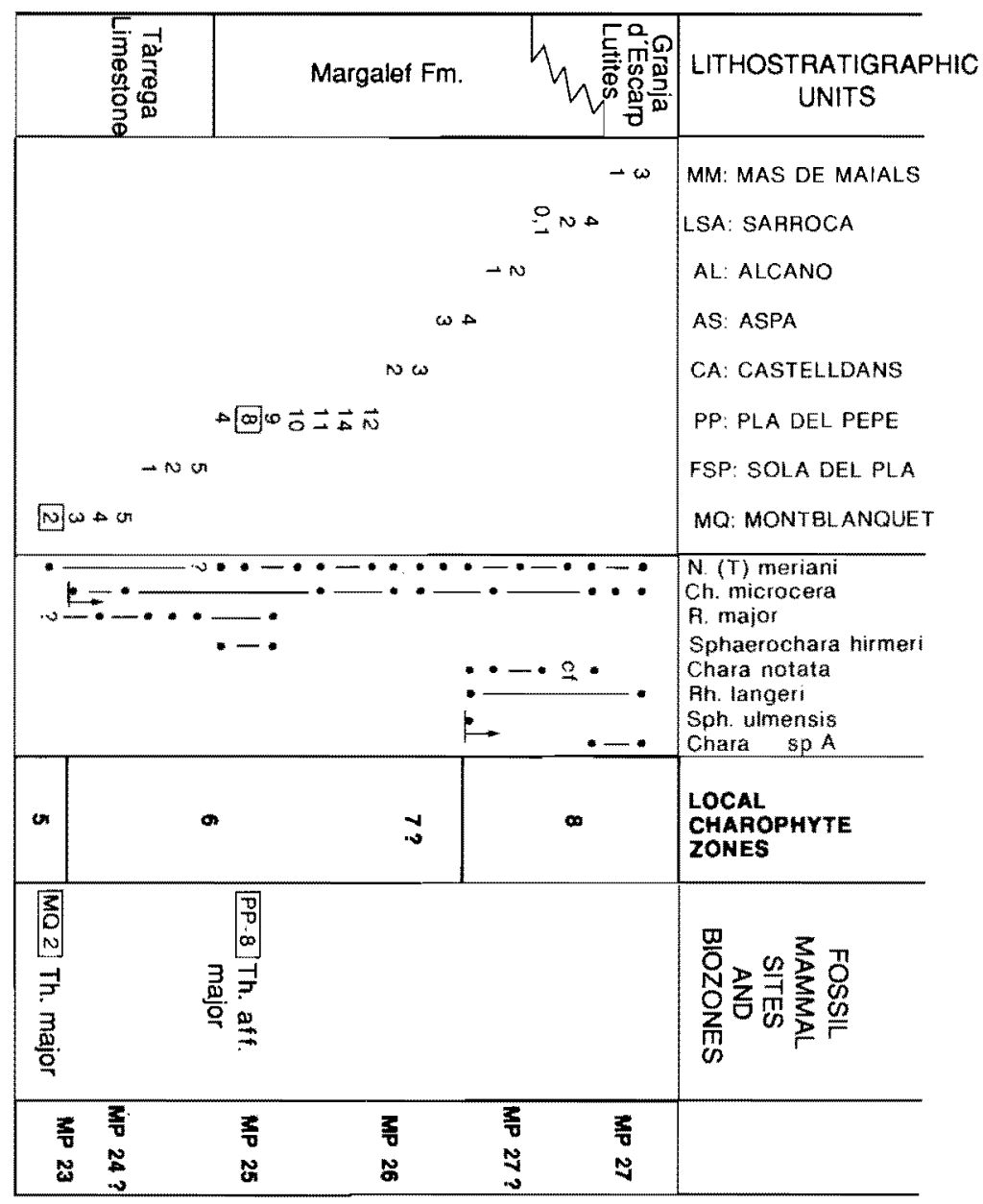

Important species: $N$, jorbae, which appears within local zone $3 ; H$. tuberculata, $S$. aff. vectensis and $R$. stockmansi persist from local zone 2.

Zonal attribution: local zone 3 is correlable in its assemblage with the Stephanochara vectensis zone of RIVELINE (1986), which must be revised from new information on the range of the index species in the Isle of Wight. In the Ebro Basin, $S$. aff. vectersis shows the same range and distribution than $H$. tuberculata. Local zone 3 is identified in the Bembrige Marls of the Isle of Wight as well as in the Lower Molasse du Fronsadais, exposed at Baby-2 and SaintCapraise localities of the Aquitaine Basin, which are referred to the MP 20 mammal standard level. In the Ebro Basin, the top of local zone 3, which is placed in the Lower Stampian MP 21-MP 22 standard levels, does not correspond to the upper limit of the Stephanochara vectensis zone that is restricted to the Late Eocene. 
Table 5 Charophyte distribution in the stratigraphic sections of Area 5 (Figs. 7 and 8).

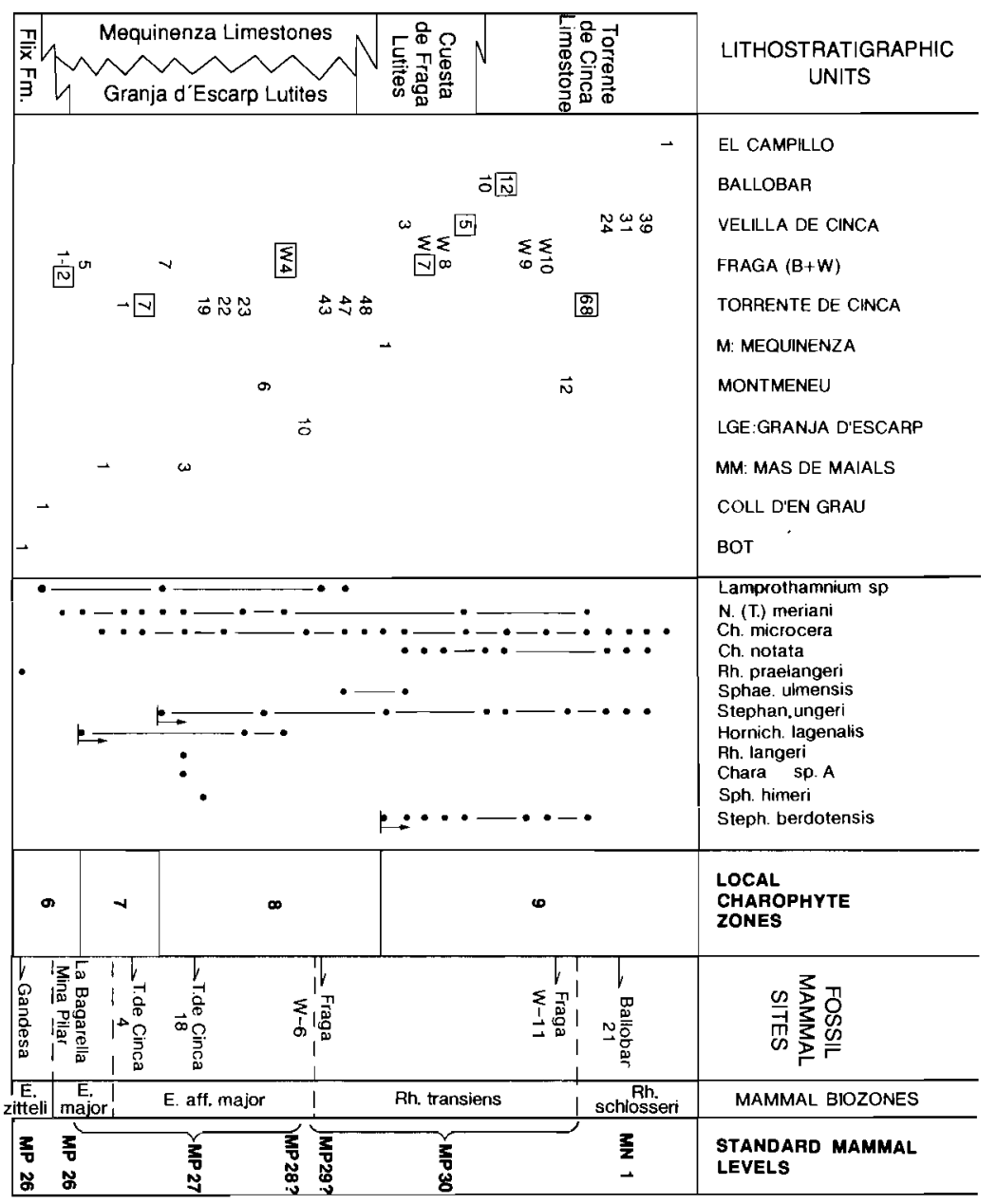

Local biozone 4

Definition: interval between the first occurrence of Nitellopsis meriani and last occurrence of Harrisichara tuberculata. Early forms of $N$. meriani occur in the Jorba-La Panadella section and the zone is developped in the Calaf, Súria, Fonollosa and Santpedor sections (Artès Formation). The base of zone 4 is placed within the Th. calafensis zone as it does in the JorbaLa Panadella section which includes its lowest occurrence.

Important species: early forms of $G$. medicaginula; last occurrences of $H$. tuberculata, $R$. stockmansi, S. subglobosa, L. longus, and S. lychnothamnoides.

Zonal attribution: local zone 4 corresponds in its assemblage to the Stephanochara pinquis zone of Riveline (1986). This zone can be referred to the MP 21 mammal standard level, by 
correlation with mammal and charophyte associations of Soumailles, Ronzon and Hoogbutsel localities. The indexspecies has not been found in the Catalan localities. In the Ebro Basin, data from the Calaf mammal faunas imply the place the upper limit of the $S$. pinquis zone in the $\mathrm{Mp} 21-\mathrm{MP} 22$. This attribution is not however consistent with the extension of the taxa which compose the assemblage of the $S$. pinquis zone, in particular the genus Harrisichara, which was never reported from the Rhabdochara major zone, correlated with the MP 22 standard level.

\section{Undefined local biozone 5}

Interval between the last occurrence of Harrisichara tuberculata and the first occurrence of Chara microcera. The uppermost part of the Jorba-La Panadella section, including bed 38 , corresponds to this interval, which is also present in the Forès-Sarral section.

Zonal attribution: Rhabdochara major zone (Rrveline (1986).

\section{Local biozone 6}

Definition: interval between the first occurrences of Chara microcera and Homichara lagenalis. Early forms of C. microcera occur in the Tàrega Formation, in Solivella-3 and Montblanquet-3. The zone is also developped in the Forès and El Talladel sections.

Important species: S. birmeri; R. major, whose presence in this interval corresponds to the upper part of its range.

Zonal attribution: local zone 6 corresponds to the lower part of the C. microcera zone of RIVELINE 1986 with an earlier lower limit, the species appearing in an horizon referred to the MP 23 standard level, instead of MP 24 as previously known (CHeLLAr et al. 1982). This newly redefined C.microcera zone is correlated with the Argiles des Milles and with the Argiles de Saint-André (South of France), the latter correlated with the MP 26 standard level.

\section{Local biozone 7}

Definition; interval between the first occurrences of Hornichara lagenalis and Stephanochara ungeri. Early form of $H$. lagenalis occur in the Flix Formation, in bed 5 of the Frage B section, correlated with the E. major zone, attributed to the MP 27 mammal standard level. This zone is developped in the lower portion of the Mequinenza Limestone, appearing in the Fraga Section.

Important species: Chara microcera, persistant from zone 6.

Zonal attribution: Homichara lagenalis zone corresponds to the Upper part of the Chara microcera zone previously defined by RrveLINE (1986). Out of the Ebro Basin, the new zone is identified in the Lower part of the "Molasse rouge" of the Geneva Basin (Berger et al. 1986); thus in the SPM5 Borehole, the lowest occurrence of H. lagenalis is below the S. ungerione, as reported in the Ebro Basin. 


\section{Local biozone 8}

Definition: interval between the first occurrences of Stephanochara ungeri and Stephanochara berdotensis. Early form of S. ungeri occurs in the Frage-7 horizon, referred to the E. aff. major zone, attributed to the MP 27 mammal standard level. This zone is represented in the Fraga, Velilla de Cinca and Mequinenza secrions.

Important species: early forms of R. langeri, Chara sp. 1 and of S. ulmensis occur within local zone 8; C. microcera.

Zonal attribution: zone 8 corresponds to the $S$. ungeri zone of Rrveline (1986) and Berger (1986). Out of the Ebro Basin, this zone is identified in the Pelarda Formation, at the Vivel del Rio and Villanueva del Rebollar mammal localities (Teruel Basin; Aorover et al. 1982), attributed to the MP 28 and MP 29, respectively; In Aquitaine, local zone 8 is developped in the upper part of the Molasse de l'Agenais, at the La Milloque locality (Feisr \& Ringeade 1977), referred to the MP 29; in the Swiss Molasse, from the Wynau to Rickenback mammal levels (Kissling 1974; Berger 1986), thus from MP 27 to MP 29.

\section{Local biozone 9}

Definition: base of zone 9 is based on the lowest occurrence of Stephanochara berdotensis. Early form of $S$. berdotensis occurs in bed 48 in the Torrente de Cinca section, referred to the $R h$. transiens mammal zone, attributed to the MP 30. Top of zone 9 is not defined due to the, up to date, not recorded occurrence of the Lower Aquitanian markers (Rantzieniella nitida Grambast, Sphaerochara davidi Feist-Castel).

Important species: Chara notata, $R$. langeri, and Chara sp. A., persisting from lower levels.

Zonal atrribution and resulting changes in the general biozonation: local biozone 9 is partially equivalent to the Chara notata biozone of Rrveline (1986) which is no longer defined, due to the new range of the index-species determined in the Ebro Basin (see above, Part III, Chara notata); the Rantzienella nitida biozone, not identified in the Ebro Basin, will be placed over the $S$. berdotensis biozone, with its new definition.

\section{B. Comparison of the Charophyte and Mammal successions}

The charophyte-mammal correlations established in the European Basins are based on a number of common localities, from the Lower Eocene onward (CAstel 1968; Ferst-Castel 1977a; Feist \& Ringeade 1977; Riveline 1986; Berger 1986; Tambareau et al. 1989).

In the Ebro Basin, the identification of the Upper Priabonian Sphaerochara labellata and Stephanochara vectensis zones in the lower sequences is compatible with data from Vertebrate faunas. In contrast, some differences appear between the two groups with regard to the identificaiton of the Lower Oligocene: the Eocene-Oligocene boundary based on the mammals is spanned without any change by the charophytes and the Lower Oligocene Stephanochara pinquis zone is developped in the Theridomys calafensis mammal zone, correlated with the Villebramar reference level. With regards to the previous charophyte records in this period, we admit that the $S$. pinquis zone may extend higher than its previous range, 
restricted to the Ronzon-Hoogbutsel-Lower Hamstead level. With regard to the Middle Stampian, only undefined local zone 5, starting with the estinction of $H$. tuberculata and finishing with the first Chara microcera, could be referred to the Rhabdochara major zone. Charophyte and mammal indications are concordant for the Upper Stampian, Upper Oligocene and Lower Miocene sequences; the unability of charophytes in defining the basal Aquitanian is due to the local absence of stratigraphically significant markers.

\section{The Ebro Basin Charophyte succession in the framework of the standard European biozonation (Table 7 )}

The zonation established in the Ebro Basin is based on continuous sections correlated one with each others inside a same area. The precision obtained in delimitating the species ranges and the composition of the successive assemblages leads to deeply modify the previous zonations. With regard with the more recent one, from RIveline (1986), the main changes consist in: 1) the suppression of two zones, which became invalid following the lengthen of the index species ranges; 2) a new definition of the Stephanochara vectensis and Chara microcera zones; 3) the adjonction of two new zones, the Sphaerochara labellata zone in the Lower Stampian and the Homichara lagenalis zone in the Upper Stampian. On the other hand, data from micromammals lead to extend the range of the assemblage characterizing the Stephanochara vectensis biozone higher than the MP-20 (Saint Capraise) level and the Stephanochara pinquis zone higher than the Ronzon level, thus between the Ronzon and Villebramar mammal standard levels.

\section{Oligocene extinction event in Charophytes}

Table 6 shows that the charophyte assemblages succed regularly in the Tertiary of the Ebro Basin. It is evident, however, that the species number varies from twenty for the three zones representing the Priabonian and Lower Stampian interval, corresponding to about five million years, to only twelve species for the whole younger zones during the same duration. Considering the assemblages represented in zone 4, we note that the extinctions of species are increasing in zone 4, from base to summit (Tables 1 and 2). These disparitions, not compensed by the recovery of new species, lead to a drastic impoverishment of the charophyte phylum during the Lower-Middle Oligocene transition.

The impoverishment of the group seems a general phenomenon derived from the extinctions occuring between the Stephanochara pinquis and Rhabdochara major zones. Charophytes being directly influenced by potential calcium carbonate precipitation, which is temperature-controlled, the Middle Oligocene cooling (KEIGwIN \& KELLER 1984) may be evocated as major factor of extinctions. This hypothesis is supported by the contrasting event of speciation during the Upper Oligocene, coinciding with the general warming which seems to have occurred during this period (MILler \& Fatrbanks 1985; VianEY-Liaud 1991).

\section{Conclusions}

As a main result of the present paper, a new charophyte zonal scheme, based on the Ebro Basin succession, is proposed for the Upper Eocene-Lower Miocene interval. Most species 
Table 6 Upper Eocene - Lower Miocene charophyte zones in the Eastern Ebro Basin and correlation with the standard mammal levels. (1) from Agustí et al. (1987) and Schmot-KitTLer et al. (1987). (2) from Haq of al. (1987).

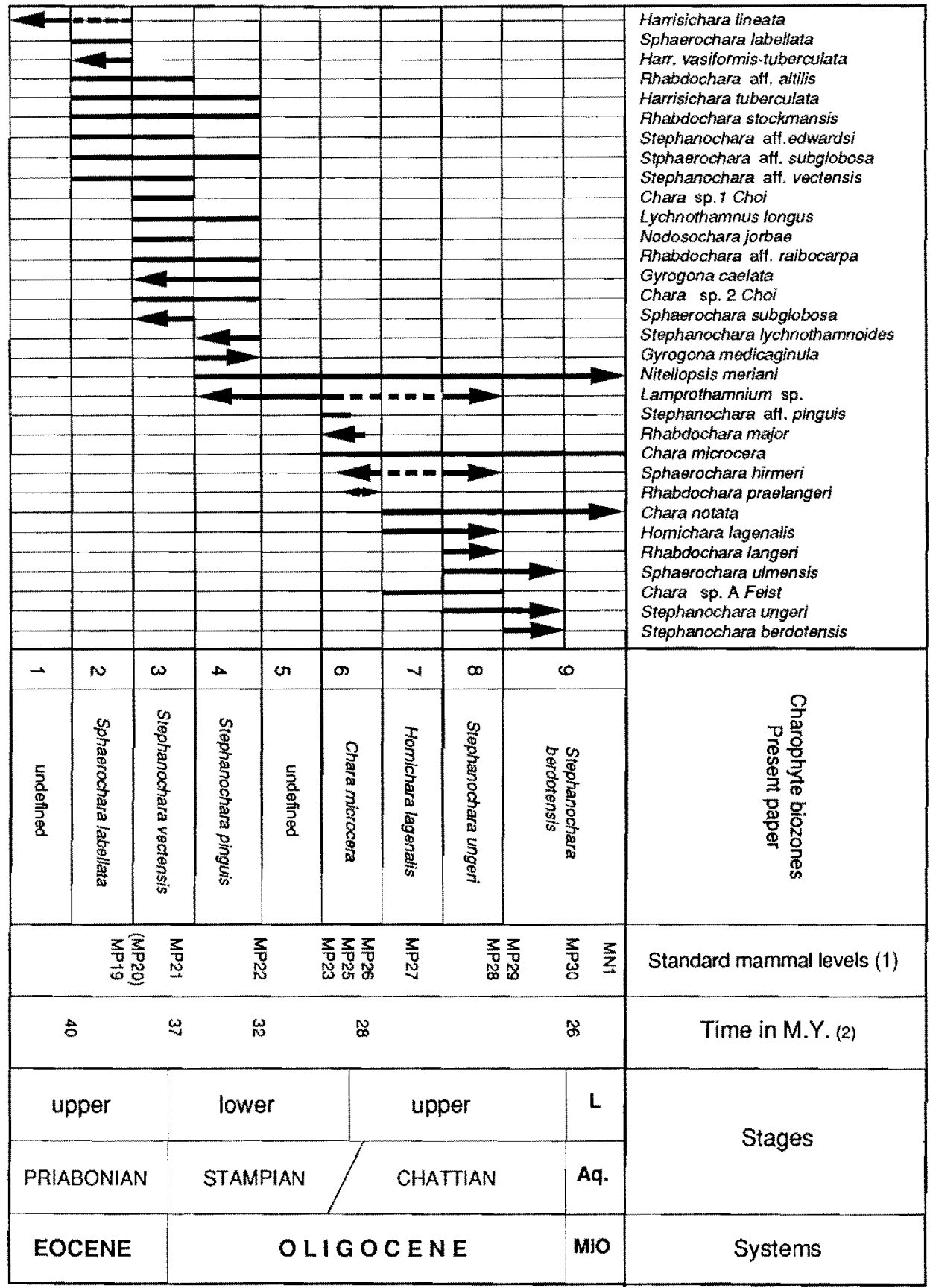


Table 7 Correspondence between the Ebro Basin charophyte zonation (4), the charophyte zonation (3) of Rrvecune (1986) and the proposed, new charophyte biozonation (7) for Western Europe (Late Eocene to Lave Oligocene). This table also shows the correspondence of the Rrvecrne (1986) charophyte biozonation with the mammal levels (2), the mammal local biozones for the Ebro Basin (5) based on AGustí et al. (1987) and the mammal reference levels (6) of SCHMIDT-Kittler ed. (1987). Note the chronostratigraphic atribution of the Riveline (1986) zones (column 1) and the present chronostratigraphic attribution (8). The differences between the chronostratigraphic correspondences of the charophyte biozonations are due to changes in the chronostratigraphic attributions of several charophyte index species.

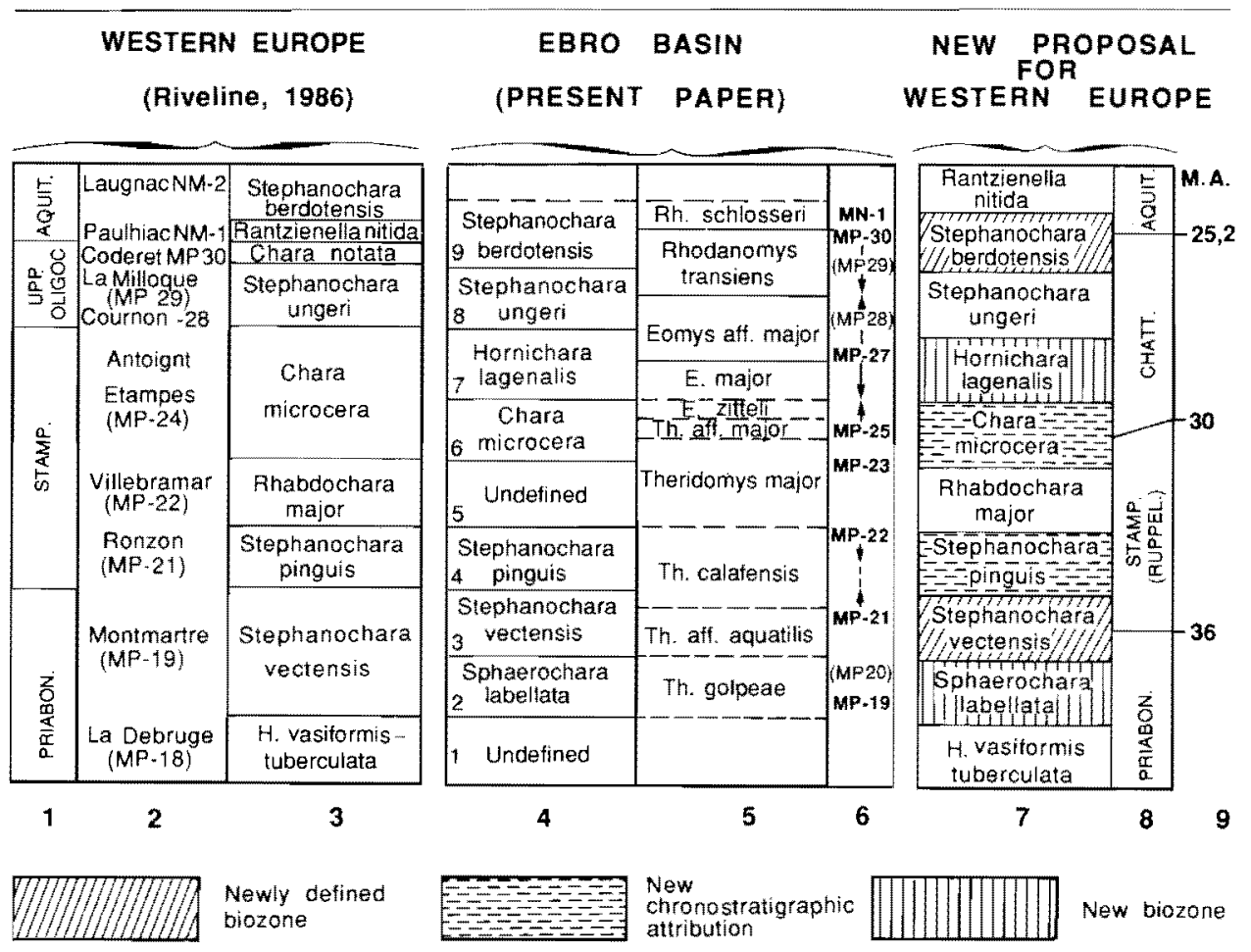

being widely distributed, the new zonal scheme is applicable to the whole Western Europe. With distant areas, only broad correlations, based on rare common species, can be presently established. Notably, such correlations can be established with Asia (China, India).

On the other hand, the comparison of the charophyte and mammal zonations shows that, from the Lower Oligocene onward, the latter is twice more precise, in contrast with the previous periods: the number of Eocene zones is similar in charophyte and mammals zonations and, for the Cretaceous, eighteen zones subdivide the Cretaceous but none has been defined sofar in the vertebrates, at least in the old world.

Finally, relations between the change in generic and specific diversity and the general climatic changes have been evidenced: decreasing diversity corresponding to the Middle 
Oligocene cooling and, contrastingly, recovering of diversity during the Upper Oligocene warming phase. We expect, from current isotopic studies, more precise data on the temperatures that prevailed, during the Oligocene, in the Ebro Basin.

Acknowledgements. We are grateful to F. Agust, S. Legendre and M. VIAney-Liaud for fruitful discussions and constructive remarks on the manuscript. These investigations have been partially been supported by a grant of the Centre National de la Recherche Scientifique (DBT2) "Changement de l'environment global" $n^{\circ} 545$ and ISEM contribution $n^{\circ} 93-014$ ).

\section{References}

Adrover, R., M. Feist, M. Huguenex, P. Mein \& E. Moissenet (1983): Les formations continentales paléogènes de la Sierra Palomera (Province de Teruel, Espagne) et leur place dans la biostratigraphie tertiaire des Chaines Ibériques Orientales. - Bull. Soc. Gêl. France. (7) 25: 421-431, Paris.

Agustí, J., P. Anadón, S. Arbiol, Ll. Cabrera, F. Colombo \& A. Sázz (1987): Biostratigraphical characteristics of the Oligocene sequences of North-Eastern Spain (Ebro and Campins Basins). Münchn. Geowiss. Abh. (A), 10: 35-42, München.

Agustí, J, Ll. Cabrera, P. Anadón \& S. Arbrol. (1988): A late Oligocene-Early Miocene rodent biozonation from the SE Ebro Basin (NE Spain): A potential mammal stage stratotype. - Newsl. Stratigr., 18:81-97, Gebrüder Borntraeger, Stuttgart/Berlin.

Anadón, P. (1978): El Palégeno continental anterior a la transgresión biarritziense (Eoceno medio) entre los rios Gaia y Ripoll (privincias de Tarragona y Barcelona). - Estudios Geol. 34: 431440.

Anadón, P. \& M. Feist (1981): Charophytes et Biostratigraphie du Palégène inférieur du bassin de l'Ebre oriental. - Palaeontographica, B, 178: 143-168, Stuttgart.

Anadón, P., M. Fetst, J.--L. Hartenberger, C. Müller \& J. Villalta-Comella (1983): Un exemple de corrélation biostratigraphique entre échelles marines et continentales dans l'Éocène: La coupe de Pontils (Bassin de l'Ebre, Espagne). - Bull. Soc. Géol. Francc, 7, 25: 747-755, Paris.

Anadón, P., Ll. Cabrera, J. Gumerà \& P. Santanach (1985): Paleogene strike-slip deformation and sedimentation along the southeastern margin of the Ebro Basin. - In: BIDdLE, K. \& N. CHRISTIEBLick (eds.): Strike-slip deformation, basin formation and sedimentation. Spec. Publ. Soc. Econ. Palcont. Mineralogists, 37: 303-318.

Anadón, P. F. Colombo, M. Estaban, M. Marzo, S. Robles, P. Santanach \& L. Solé Sugrañes (1979): Evolución tectonoestratigráfica de los Catalánides. - Acta Geol. Hispanica, 14: 242-270.

Anadón, P. M. Vianex, Liaud, Ll. Cabrera \& J. L. Hartenberger (1987): Gisements à vertébrés du Paléogène de la zone orientale du basin de l'Ebre et leur apport à la stratigraphie. - Paleont. i Evol., 21: $117-131$.

Anadón, P. L. Cabeera, B. Colldeforns \& A. Saez (1989): Los sistemas lacustres del Eoccno superior y Oligoceno del sector oriental de la Cuenca del Ebro. - Acta Geol. Hispanica, 24: $205-230$.

BAUMgartner, K. (1985): Erstuachweis von Gyrogona medicaginula Lamarck (Characeae) aus der Unte* ren Süsswassermolasse Bayerns. - Münchner Geowiss. Abh. (A), 6: 45-50.

Berger, J.-P. (1986): Biozonation préliminaire des charophytes oligocènes de Suisse occidentale. - Eclogae geol. Helv, 79: $897-912$.

BURNe, R. V., J. BAULD \& P. DE DEcker. (1980): Saline lake charophytes and their geological significance. - J. Sedim. Petrol, 50:281-293.

CABrera, L. (1983): Estratigrafía y sedimentología de las formaciones lacustres del tránsito OligocenoMioceno del SE de la Cuenca del Ebro. - Tesis doctoral, Univ. de Barcelona, 443 pp. Inédito.

CAstel, M. (1968): Zones de charophytes pour l'Oligocène d'Europe occidentale. - C. R, somm. Soc. géol. Fr, 4: 121-122. 
Chellai, El H., S. Baudelot, B. Crochet, M. Feist \& M. Durand-Delga (1982): Preuves paléontologiques de lantériorité des conglomérats de la Grésigne (Eocène supérieur) par rapport à la Molasse oligocène de l'Albigeois (Tarn). - C. R. Acad. Sci. Paris, 295: sér. 2: 683-690.

CHol, S. J. (1989): Les charophytes du bassin potassique catalan (Nord-est de l'Espagne) à la limite Eocène-Oligocène. - Paléobiologie continentale, 26: 1-67.

Colom, G., L. Vha \& S. Reguant (1970): Hallazgo de Harrisichara lineata Grambast en el yacimiento del Parés (Sant Boi del Lluçanés, Vic). - Acta Geol. Hispanica, 5; 65-66.

Colomno, F. (1980): Estratigrafia y sedimentología del Terciario inferior continental de los Catalánides. Tesis doc. Univ, de Barcelona, 608 p. Inćdito.

- (1986): Estrangrafía y sedimentología del Paleogeno continental del borde meridional occidental de los Catalándes (Provincia de Tarragona, Españal. - Cuad. Geol. Ibérica, 10: 55-115.

Dalloni, M. (1930): Etudes géologiques des Pyrences Catalanes. 292 p., Edit. Carbonnel, Alger.

Feist-Castel, M. (1971): Sur les Charophytes fossles du bassin Tertiaire d'Ales. - Géobios, 4: 157-172, Lyon.

- (1977a): Evolution of the charophyte floras in the Upper Eocene and Lower Oligocene of the Isle of Wight. Palaeontology, 20,1:143-157, London.

- (1977b): Eude floristique et biostratigraphique des charophytes dans les sêries du Paléogène de Provence.-.- Géol. Médit., 4: 109-138, Marseille.

- (1977c): Description du nouveau genre Krassavinella (Charophytes, Characeae) et répartition de $K$. lagenalis (Straub) dans l'Oligocene supérieur de la Molasse Suisse, - Ecl. geol. Helv., 70: 771-775, Basel.

FEIST, M. \& M. RINGeade (1977): Etude biostratigraphique et paleobotanique (charophytes) des formations continentales d'Aquitaine, de l'Eocène supérieur au Miocène inférieur. - Bull. Soc. geol, Fr, 7 , $19: 341-354$.

Ferrer, J. (1971): El Paleoceno y Eoceno del borde sur-oriental de la depresión del Ebro (Cataluña). Mém. Suiss. Paléont., 90: 1-70.

Fischer, W. L. \& J. H. McGowen (1969): Depositional systems in the Wilcox Group (Eocene) of Texas and their relationship to occurrence of oil and gas. - Am. Ass. Petrol. Geol. Bull., 65: 653-673.

Grambast, L. (1962): Sur l'intérêt stratigraphique des Charophytes fossiles: exemples d'application au Terriaire parisien. - C. R. somm. Soc. géol. Fr., 7: 207-208.

Grambast, L. (1972): Principes de l'utilisation stratigraphique des charophytes. Applications au Paleogène d'Europe occidentale. - Mém. Bur. Rech. géol. Min., 77: 319-328, Paris.

Groves, J. (1926): Charophyta. - In: Reid, E. M. \& M. E. Chandoler: The Bembridge Flora. - Brit. Mus. Cat. Cainoz. Plants I, 206 p, London.

Haq, B. U. \& F. W. B. van Eysinga (1987): Geological time table. Elsevier, Amsterdam.

HORN, AF RANTZtEN, H. (1959): Morphological types and organ-genera of Tertiary charophyte fructifications. Stockholm Contrib, Geol., 4: 45-197.

KEIGWIN, L. \& G. KELLER (1984): Middle Oligocene cooling from equatorial Pacific DSDP site 77B. Geology, 12: 16-19.

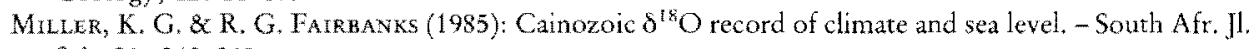
$\operatorname{Sci}_{,} 81: 248-249$.

Papp, A. (1951): Charophytenreste aus dem Jungtertiar Osterreichs. - Osterr. Akad. Wiss. Math. Nat. Kl. Sitzungber, 160: 279-293, Wien.

Puicoffarkeas, C., J. A. Muñoz \& M. Marzo (1986): Thrust belt development in the Eastern Pyrenees and related depositional sequences in the southern foreland basin. - In: PH. ALLEN \& P. HOMEWOOO (eds.): Foreland basins. Spec. Publ. I.A.S., 8: 229-246.

Ramirez oel Pozo, J., O. Riba \& A. Maldonado (1975a): Mapa Geológico de España, E. 1:50,000. Hoja n. 362: Calaf. - Serv. Publ Min. Industria.

Ramirez del Pozo, J., O. Riba \& A. Maldonado (1975b): Mapa Geológico de España, E. 1:50,000. Hoja n. 330: Cordona. - Serv. Publ. Min. Industria.

Rivelne, J. (1986): Les Charophytes du Paléogène et du Miocène inférieur d'Europe Occidentale.Cahiers de Paleontologie. Editions du CNRS, 227 pp, 38 pl. 
Rosell, J., R. Julià \& J. Ferrer (1966): Nota sobre la estratigrafís de unos niveles con carófitas existentes en el tramo rojo de la base del Eoceno al $\mathrm{S}$. de los Catalánides (provincia de Barcelona). - Acta Geol. Hispanica, 1: 17-20.

SÁEz, A. (1987): Estratigrafía y sedimentología de las formaciones lacustrés del tránsito Eoceno-Oligoceno del NE de la Cuenca del Ebro. - Tesis doctoral, Universidad de Barcelona, Servei de Publications de la Univ. de Barcelona, ed. microficha, $353 \mathrm{pp}$.

SChMidT-KItTLER, N. (1987): European reference levels and correlation tables. - International Symposium on Mammalian Biostratigraphy and Paleoecology of the European Paleogene, Mainz, February 18th - 21st 1987. Münchner Geowiss. Abh. (A), 10: 15-19.

StrauB, E. W. (1952): Mikropaläontologische Untersuchungen im Tertiär zwischen Ehingen und Ulm an der Donau. - Geol. Jb., 66: 433-524, Hannover.

Tambareau, Y., M. Feist, C. Gruas-Cayagnetto \& M. Murru (1989): Caractérisation de l'llerdien continental dans le domaine ouest-méditerranéen. C.R. Acad. Sci. Paris, 308: 689-695. [Engl abr, version]

Vianey-Liaud, M. (1991): Les rongeurs de l'Eocène terminal et de l'Oligocéne d'Europe comme indicatuers de leur environnement. Palaeogeogr., Palaeoclim., Palaeoecol., 85: 15-28. Elsevier, Amsterdam.

Xin Lun, IN Wang, Huang, Yang \& LeE (1978): Early Tertiary charophytes from coastal region of Bohai, 49p, 23 pl., Nanjing. [In Chinese, Engl. Abstract]

Typescript received 13.11 .1992 